\title{
Magnetic Nanoclusters Coated with Albumin, Casein, and Gelatin: Size Tuning, Relaxivity, Stability, Protein Corona, and Application in Nuclear Magnetic Resonance Immunoassay
}

\author{
Pavel Khramtsov 1,2,*(1), Irina Barkina ${ }^{2}$, Maria Kropaneva ${ }^{1}$, Maria Bochkova ${ }^{1}$, \\ Valeria Timganova ${ }^{1}$, Anton Nechaev ${ }^{3}$, Il'ya Byzov ${ }^{1,4}$, Svetlana Zamorina ${ }^{1,2}$, \\ Anatoly Yermakov ${ }^{1,4,5}$ and Mikhail Rayev ${ }^{1,2}$ \\ 1 Laboratory of Ecological Immunology, Institute of Ecology and Genetics of Microorganisms of the Ural \\ Branch of the Russian Academy of Sciences, Branch of PSRC UB RAS, 13 Golev str., 614081 Perm, Russia; \\ kropanevamasha@gmail.com (M.K.); krasnykh-m@mail.ru (M.B.); timganovavp@gmail.com (V.T.); \\ ivbyzov@gmail.com (I.B.); mantissa7@mail.ru (S.Z.); yermakov@imp.uran.ru (A.Y.); mraev@iegm.ru (M.R.) \\ 2 Department of Microbiology and Immunology, Biology Faculty, Perm State National Research University, \\ 15 Bukirev str., 614000 Perm, Russia; i_barkina@mail.ru \\ 3 Institute of Technical Chemistry of Ural Branch of the RAS, 3 Academician Korolev str., 614013 Perm, Russia; \\ toxambj@gmail.com \\ 4 M.N. Mikheev Institute of Metal Physics of the Ural Branch of the Russian Academy of Sciences, \\ 18 S. Kovalevskoy str., 620108 Yekaterinburg, Russia \\ 5 Ural Federal University named after the first President of Russia B.N. Yeltsin, 19 Mira str., \\ 620002 Yekaterinburg, Russia \\ * Correspondence: khramtsovpavel@yandex.ru; Tel.: +7-342-280-77-94
}

Received: 26 August 2019; Accepted: 18 September 2019; Published: 19 September 2019

\begin{abstract}
The surface functionalization of magnetic nanoparticles improves their physicochemical properties and applicability in biomedicine. Natural polymers, including proteins, are prospective coatings capable of increasing the stability, biocompatibility, and transverse relaxivity ( $\mathrm{r} 2$ ) of magnetic nanoparticles. In this work, we functionalized the nanoclusters of carbon-coated iron nanoparticles with four proteins: bovine serum albumin, casein, and gelatins A and B, and we conducted a comprehensive comparative study of their properties essential to applications in biosensing. First, we examined the influence of environmental parameters on the size of prepared nanoclusters and synthesized protein-coated nanoclusters with a tunable size. Second, we showed that protein coating does not significantly influence the $\mathrm{r} 2$ relaxivity of clustered nanoparticles; however, the uniform distribution of individual nanoparticles inside the protein coating facilitates increased relaxivity. Third, we demonstrated the applicability of the obtained nanoclusters in biosensing by the development of a nuclear-magnetic-resonance-based immunoassay for the quantification of antibodies against tetanus toxoid. Fourth, the protein coronas of nanoclusters were studied using SDS-PAGE and Bradford protein assay. Finally, we compared the colloidal stability at various $\mathrm{pH}$ values and ionic strengths and in relevant complex media (i.e., blood serum, plasma, milk, juice, beer, and red wine), as well as the heat stability, resistance to proteolytic digestion, and shelf-life of protein-coated nanoclusters.
\end{abstract}

Keywords: nanoparticles; protein; assay; colloidal stability; antibody; protein G; streptavidin

\section{Introduction}

Magnetic nanoparticles find application in numerous fields of biomedicine, including drug delivery, tissue engineering, bioimaging, biosensing, and many others [1,2]. The magnetic nanoparticle-assisted 
isolation of cells, proteins, DNA, and other analytes from such complex matrices as whole blood, blood serum or plasma, urine, tissue extracts, food, and liquor are a powerful tool in biosensing, facilitating increases in analytical sensitivity and specificity [3]. Recently, magnetic nanoparticles have been extensively used in optical, electrochemical, and piezoelectric sensors, as well as in colorimetric point-of-care tests serving as tags, carriers of labels (e.g., enzymes), or both [4,5].

Nuclear magnetic resonance (NMR)-based biosensing is an area where magnetic nanoparticles are filling an extremely important role. The ability of magnetic nanoparticles to perturb the precession of nuclear spins in surrounding water protons stipulates their application in vivo as a magnetic resonance imaging (MRI) contrast [6] and in vitro as a nanoprobe for NMR-relaxometry [7]. There are two main approaches to in vitro NMR-assays. The first is a magnetic relaxation switch (MRSw), which relies on the aggregation of magnetic nanoparticles caused by the addition of an analyte. The aggregation/disaggregation of nanoparticles leads to a change in transverse relaxation time of protons (T2). The second approach is based on the binding of magnetic nanoparticles to the target and the removal of unbound particles. In this case, the relaxation time depends on the number of nanoparticles in the sample; this number is proportional to the analyte concentration. A detailed description of the principles underlying NMR sensors can be found in reviews [8-10]. NMR sensing platforms exploiting magnetic nanoparticles are used in food safety assessment; the diagnostics of sepsis, hemostatic disorders, and infectious diseases; and the detection of extracellular vesicles, tumor markers, enzymes, and ions [10-12]. Despite great progress in the field of magnetic sensing, improvements in the stability, relaxivity, and biocompatibility of magnetic nanolabels are of great importance for both in vivo and in vitro diagnostics $[7,13,14]$.

Magnetic nanoparticles, a key element of NMR sensors, suffer from an instability in water solutions, the nonspecific sorption of molecules from the environment, and a lack of surface functional groups. Numerous surface coatings have been developed to address these challenges: polymers (e.g., dendrimers, polyvinylpyrrolidone, polyethylene glycol (PEG) and polyethyleneimine), zwitterions, small molecules (e.g., citrate), and inorganic materials (e.g., silica and gold) [6,15]. Proteins and polypeptides, as well as carbohydrates and lipids, are other prospective shielding agents to endow magnetic nanoparticles with stability in physiological media, biocompatibility, stealth properties, and multiple surface functional groups [16-22].

The goal of this study is to provide a direct comparison of the colloidal stability, functional activity, and physical-chemical properties of nanoclusters consisting of magnetic carbon-encapsulated iron nanoparticles coated with four proteins widely used in biomedicine: bovine serum albumin (BSA), casein, and gelatins A and B. We studied these nanoconjugates in the context of their application for in vitro assays, and more specifically, for T2 relaxometry. We chose the mentioned proteins for the following reasons:

(1) Serum albumin and casein coatings can increase the $\mathrm{r} 2$ relaxivity of magnetic nanoparticles due to their high hydrophilicity and ability to retain water molecules [13,23]. Gelatin has a strong affinity toward water molecules [24]; therefore, it is of great importance to reveal whether it can also increase relaxivity of magnetic nanoparticles.

(2) All proteins under study are extensively used for the preparation of nanoplatforms in drug delivery and theranostics because of their biocompatibility and excellent stability in physiological solutions $[20,25,26]$. The potential risks of human exposure to nanoparticles are still not well understood [27]; therefore, it is essential to ensure the biocompatibility of nanomaterials, even when they are designed for in vitro applications.

(3) BSA, gelatin, and casein are widely utilized as carriers for fluorophores, T1-contrast agents, enzymes, and therapeutics $[20,25,26]$, therefore, the loading of a protein coating with agents providing multimodal biosensing is available.

(4) Albumin coatings decrease the nonspecific adsorption of serum proteins on the nanoparticles' surface [17], facilitating a reduction in false-negative results for assays.

(5) Bovine serum albumin, casein, and gelatin are relatively inexpensive and widely available biopolymers. 
To our knowledge, there remains a lack of comprehensive comparative studies of magnetic nanoparticles with different protein coatings. It is important that we examine the properties of protein-coated nanoclusters in parallel under the same conditions; we believe that only such an approach can provide an accurate comparison.

\section{Materials and Methods}

\subsection{Materials}

Fe@C nanoparticles were synthesized as described elsewhere [28]. Sepharose CL-6B was from GE Healthcare (USA), nitrocellulose membrane SCWP, $8 \mu \mathrm{m}$ pore size was from Merck (USA). Dialysis tubing with $10 \mathrm{kDa}$ MWCO was from Thermo (USA). Bovine serum albumin (heat shock isolation), agarose was from Amresco (USA), casein (lot\# C5890), gelatin type A gel strength 300 (lot\# G2500), gelatin type B gel strength 75 (lot\# G6650), biotinamidohexanoic acid N-hydroxysuccinimide ester, PEG $35 \mathrm{kDa}$, sodium dodecyl sulfate (SDS), $\beta$-mercaptoethanol, 4-aminobenzylamine, $\mathrm{NaNO}_{2}$ were from Sigma-Aldrich (USA). Streptavidin was from ProspecBio (Israel), recombinant protein G from Streptococcus sp. was kindly provided by Dr. Tatyana Gupalova, Institute of Experimental Medicine (St.-Petersburg, Russia). Tetanus toxoid was from Mikrogen (Russia), WHO standard of anti-tetanus IgG (TE-3) was from NIBSC (UK), sodium azide, ammonium persulphate, and glutaraldehyde (50\%) were from AppliChem (Germany). Sodium hydroxide, glycerol, sodium chloride, sodium hydrogen phosphate, sodium dihydrogen phosphate, and Tween-20 were from Panreac (Spain). Bradford reagent, acrylamide, TEMED, Coomassie Brilliant Blue G-250, Bromphenol Blue were from Bio-Rad (USA), trypsin was from Samson-Med (Russia).

The following solutions were used: phosphate buffer solution (PBS, $0.15 \mathrm{M} \mathrm{NaCl}, 0.015 \mathrm{M}$ $\mathrm{Na}_{2} \mathrm{HPO}_{4}, 0.015 \mathrm{M} \mathrm{NaH}_{2} \mathrm{PO}_{4}$, and $0.1 \% \mathrm{NaN}_{3}, \mathrm{pH} 7.25$ ) and PBS-Tw (PBS + 0.1\% Tween-20). A 25\% $(v / v)$ glutaraldehyde solution with $\mathrm{pH} 7.25$ was prepared by mixing of $50 \%$ glutaraldehyde with PBS; $\mathrm{pH}$ and ionic strength were adjusted with $1 \mathrm{M} \mathrm{NaOH}$ and $5 \mathrm{M} \mathrm{NaCl}$ respectively. The solution of casein in water was prepared as follows: first, $2.5 \mathrm{mg}$ of casein powder was diluted in $47.5 \mathrm{~mL} 1 \mathrm{M}$ $\mathrm{NaOH}$ and dialyzed twice against $5 \mathrm{~L}$ of $0.1 \mathrm{M} \mathrm{NaCl}$ and once against $5 \mathrm{~L}$ of deionized water; then casein was concentrated to $25-30 \mathrm{~mL}$ using PEG 35000 and centrifuged at 20,000 $\times \mathrm{g}$ for $100 \mathrm{~min}$ to remove the most of micelles (Figure S1). The final concentration of casein $(8.8 \%)$ was determined using an extinction coefficient of $0.81 \mathrm{~L} \cdot \mathrm{g}^{-1} \cdot \mathrm{cm}^{-1}$ [29]. All solutions were prepared using deionized water.

Blood serum samples were from volunteers aged from 21 to 58 years. All the procedures performed in the studies involving human participants were in accordance with the 1964 Declaration of Helsinki and its later amendments or comparable ethical standards. This research was approved by the Review Board of the Institute of Ecology and Genetics of Microorganisms UB RAS (IRB00010009). Written informed consent was obtained from the volunteers.

The following equipment was used: UV-VIS spectrophotometer Shimadzu UVmini 1240, an Asylum Research atomic-force microscope (United States), an MSE Soniprep 150 sonicator, a Malvern ZetaSizer Nano ZS particle analyzer, TGA/DSC1 (Mettler-Toledo) was employed to perform the thermogravimetric analysis (TGA), chromatography columns XK 16/40 and C 10/10, peristaltic pump P-1 were from GE Healthcare (USA), Mini Protean tetra cell and Mini-Sub GT cell for vertical and horizontal electrophoresis were from Bio-Rad.

A custom-made NMR relaxometer was used for the NMR-assay of antibodies and nanoparticle stability studies. The magnet assembly of the device was based on permanent SmCo magnets with a field of $\sim 2 \mathrm{kOe}\left(0.2\right.$ Tesla), with a heterogeneity of no more than $3 \times 10^{-5}$ in the sample volume $\left(1 \mathrm{~cm}^{3}\right)$, that provides a measuring frequency of approximately $7.75 \mathrm{MHz}$. The reference frequency of the device was adjusted with an accuracy of $10 \mathrm{~Hz}$ to the Larmor resonance frequency of water protons in the sample to compensate for the temperature drift of the field before the measurement.

The device was based on the Analog Devices BF-937 DSP processor. Communication with a computer was carried out via USB; custom-made software was used to interact with a PC, through 
which the device was controlled. The same software was used for the mathematical processing of the results, including the calculation of the relaxation times.

The measuring unit was inserted into the magnet assembly of the NMR relaxometer and consisted of radio-frequency coils and capacitors in a 3D-printed plastic (PLA) case. Two different measuring units were constructed: one for liquid samples, from 10 to $100 \mu \mathrm{L}$, placed in the wells of a standard 96-well-striped ELISA plate, and the other one with a flattened coil $(10 \times 10 \times 1 \mathrm{~mm})$ for the NMR measurement of liquids in flat porous membranes. For the well-based measuring system, the SNR (signal-to-noise ratio) was 43 for a liquid volume of $10 \mu \mathrm{L}$ and 378 for a liquid volume of $100 \mu \mathrm{L}$. For the planar system, the SNR was 15 for a liquid volume of $10 \mu \mathrm{L}$ in the membrane; this value was more than enough to make reliable measurements of the relaxation times.

\subsection{Preparation of Aminated Fe@C (Fe@C-NH $\left.\mathrm{H}_{2}\right)$}

First, $100 \mathrm{mg}$ of Fe@C powder was added to $10 \mathrm{~mL}$ of $1 \mathrm{M} \mathrm{HCl}$ and left for $60 \mathrm{~min}$ at room temperature (RT), then washed five times with $10 \mathrm{~mL}$ of deionized water using magnetic separation and redispersed in $10 \mathrm{~mL}$ of $1 \mathrm{M} \mathrm{HCl}$. Next, $120 \mu \mathrm{L}$ of 4-aminobenzylamine (4-ABA) was added; afterwards, a glass tube with nanoparticles was placed at $-20{ }^{\circ} \mathrm{C}$ for $30 \mathrm{~min}$, then $70 \mathrm{mg}$ of $\mathrm{NaNO}_{2}$ was added, and the resulting mixture was sonicated ( $6 \mathrm{~mm}$ probe, $100 \%$ amplification). When heating produced by the sonicator led to boiling and foaming, the sonication was interrupted to allow cooling. The total time of sonication was $60 \mathrm{~min}$. Afterwards, the suspension was placed in $10 \mathrm{kDa}$ MWCO dialysis tubing and dialyzed three times against $2 \mathrm{~L}$ of deionized water. The resulting suspension was transferred into the plastic tube and stored at $+4{ }^{\circ} \mathrm{C}$; then, $100 \mu \mathrm{L}$ of $1 \mathrm{M} \mathrm{HCl}$ was added to prevent sedimentation of aminated nanoparticles. The concentration of Fe@C- $\mathrm{NH}_{2}$ was determined by thermogravimetric analysis (TGA) and can be found in the table (Table S1).

\subsection{Influence of $\mathrm{pH}$, Ionic Strength and Protein-to-Nanoparticle Ratio on the Size of Protein-Coated Nanoclusters}

Casein, BSA, and gelatins A and B were diluted in buffers with $\mathrm{pH}$ that ranged from 4 to 9 (pH 4 and 5-acetic buffer, $\mathrm{pH} 6,7$, and 8-phosphate buffer, and $\mathrm{pH} 9$-borate buffer). The initial ionic strength of the buffers was $0.01 \mathrm{M}$, and it was adjusted to 0.15 and $0.5 \mathrm{M}$ with $5 \mathrm{M} \mathrm{NaCl}$ where necessary. Fifty microliters of $10 \mathrm{mg} / \mathrm{mL}$ Fe@C- $\mathrm{NH}_{2}$ was added dropwise under vortex stirring, then water and $1 \mathrm{M} \mathrm{NaOH} / 1 \mathrm{M} \mathrm{HCl}$ were added to make a final volume of $500 \mu \mathrm{L}$ and a $\mathrm{pH}$ of 7.2-7.6. The resulting protein-to-nanoparticle mass ratios were 10:1, 5:1, 2.5:1, and 1.25:1. The suspensions were sonicated for $10 \mathrm{~s} \mathrm{(} 30 \%$ amplification, $3 \mathrm{~mm}$ probe), added while vortexing to an equal volume of $25 \%$ glutaraldehyde solution (see Section 2.1) and incubated for $30 \mathrm{~min}$ on a rotating mixer. For BSA and casein, all steps were carried out at room temperature, while the gelatin solutions and gelatin-coated nanoclusters were kept at $+37-+40^{\circ} \mathrm{C}$ to prevent gelation.

\subsection{Synthesis of Protein-Coated Fe@C-NH $\mathrm{H}_{2}$ Nanoclusters Conjugated with Streptavidin and Streptococcal Protein $G$}

The general protocol for nanocluster conjugation with affine compounds is described in this section. The details of the synthesis procedure depended on the type of protein coating (BSA, casein, and gelatins type $A$ and $B$ ), target nanocluster size, recognition molecule (streptavidin or protein $G$ ) and purpose (e.g., we did not add BSA, glycerol, or glycine to conjugates that were used in the UV-VIS, proteolysis, and protein corona studies) and can be found in Supporting Information.

The suspension of Fe@C- $\mathrm{NH}_{2}(10 \mathrm{mg} / \mathrm{mL})$ was added dropwise under vortex stirring into a protein solution. Where necessary, the $\mathrm{pH}$ was adjusted to 7.25 with $1 \mathrm{M} \mathrm{NaOH}$, and the volume was adjusted with PBS. The final protein-to-nanoparticle ratio (mg:mg) was 5:1. The resulting suspension was added dropwise under vortex stirring to an equal volume of a $25 \%$ glutaraldehyde solution (see Section 2.1) and incubated on a rotating mixer (hereinafter, the rotation angle was set to $99^{\circ}$, and the rotation rate was $5 \mathrm{rpm}$ ) for $30 \mathrm{~min}$. Then, the nanoclusters treated with glutaraldehyde were passed through a chromatography column to remove the excess of coating protein and glutaraldehyde. Fractions 
containing Fe@C-NH $/$ /Protein nanoclusters were collected and concentrated in dialysis tubing (10 kDa MWCO, $2 \mathrm{~mL} / \mathrm{m}$ ) covered with a layer of $35 \mathrm{kDa}$ PEG. In 2-3 h, the concentrated suspension was removed from the dialysis tubing and centrifuged at $1600 \times g$ for $5 \mathrm{~min}$. The supernatant containing Fe@C-NH$/$ Protein nanoclusters activated with glutaraldehyde was added to a solution of the desired recognition molecule (streptavidin or protein $\mathrm{G}$ ) in PBS under vortex stirring. The final recognition molecule-to-Fe@C-NH $2 /$ Protein ratios ( $\mu \mathrm{g}: \mathrm{mg}$ ) were 10:1. 20:1, 40:1, 80:1, and 160:1. Conjugation was carried out overnight in a rotating mixer at $+4{ }^{\circ} \mathrm{C}$; glycine was added up to $6 \mathrm{mM}$ to quench unreacted aldehyde groups, and the mixture was incubated at RT for one more hour. The excess of reactants was removed by gel-chromatography. The fractions with the highest concentration of nanoclusters were combined. Glycerol, BSA, and glycine were added to the final concentrations of $20 \%, 1 \%$, and $6 \mathrm{mM}$, respectively. The conjugates were stored at $+4{ }^{\circ} \mathrm{C}$. The concentration of nanoclusters was determined by the absorbance at $450 \mathrm{~nm}$, taking into account that the absorbance of a suspension of protein-coated nanoclusters with a known concentration (before the addition of glutaraldehyde) was preliminarily measured.

\subsection{Assessment of Functional Activity of Protein-Coated Nanoclusters and Determination of Anti-Tetanus Toxoid in Serum Samples by NMR-Based Assay}

The solid phase NMR-based immunoassay on nitrocellulose strips was used to assess the functional activity of different sizes of Fe@C-NH $2 /$ Protein/Str. Test-strips $(5 \mathrm{~mm} \times 60 \mathrm{~mm})$ were cut from nitrocellulose with an $8 \mu \mathrm{m}$ pore size. The test-strips were soaked in PBS for $5 \mathrm{~min}$ at $+37^{\circ} \mathrm{C}$. Two microliters of biotinylated BSA (Bi-BSA) 10-fold diluted in PBS (from $100 \mu \mathrm{g} / \mathrm{mL}$ to $0.1 \mu \mathrm{g} / \mathrm{mL}$ ) was spotted onto wet strips [30], which were further dried at $+37^{\circ} \mathrm{C}$ for $30 \mathrm{~min}$ and at RT for $15 \mathrm{~min}$. Two microliters of $100 \mu \mathrm{g} / \mathrm{mL}$ BSA was spotted in the control zone. All subsequent steps were performed at $+37^{\circ} \mathrm{C}$ on an orbital shaker except for the measurement. The test-strips were blocked in $3.5 \mathrm{~mL}$ of $1 \%$ BSA in PBS-Tw, washed three times for $5 \mathrm{~min}$ in $5 \mathrm{~mL}$ of PBS-Tw, incubated in $3.5 \mathrm{~mL}$ of a $0.05 \mathrm{mg} / \mathrm{mL}$ solution of Fe@C-NH$/$ Protein/Str in PBS-Tw with 1\% BSA for $60 \mathrm{~min}$, and then washed 12 times in $5 \mathrm{~mL}$ of PBS-Tw. Parts of the test strip with spotted Bi-BSA were placed inside the coil of the relaxometer.

For the detection of the anti-tetanus toxoid $\operatorname{IgG}$, a nitrocellulose membrane with a pore size of $8 \mu \mathrm{m}$ was cut into $6 \mathrm{~mm} \times 80 \mathrm{~mm}$ pieces and soaked in PBS for $5 \mathrm{~min}$ at $+37^{\circ} \mathrm{C}$. Then, the wet membrane was incubated in $1.5 \mathrm{~mL}$ of a $20 \mu \mathrm{g} / \mathrm{mL}$ solution of tetanus toxoid in PBS for $30 \mathrm{~min}$, dried successively at $+37^{\circ} \mathrm{C}$ for $30 \mathrm{~min}$ and at room temperature for $15 \mathrm{~min}$, blocked in $1.5 \mathrm{~mL}$ of $1 \%$ BSA + $2 \%$ casein in PBS-Tw and triple washed with $1.5 \mathrm{~mL}$ of PBS-Tw for $5 \mathrm{~min}$. Then, membranes coated with the tetanus toxoid were cut into 16 pieces $(6 \mathrm{~mm} \times 5 \mathrm{~mm})$ (further referred to as "test strips") which were used in subsequent procedures. The test strips were incubated in $400 \mu \mathrm{L}$ of serum samples diluted 200-fold in PBS-Tw with 1\% BSA and 2\% casein for $60 \mathrm{~min}$, washed three times with $600 \mu \mathrm{L}$ of PBS-Tw and incubated in $400 \mu \mathrm{L}$ of $0.05 \mathrm{mg} / \mathrm{mL}$ Fe@C-NH$/$ Protein/G (nanoclusters conjugated with protein G) in PBS-Tw with $2 \%$ casein for $60 \mathrm{~min}$ and washed 12 times. Solutions of the WHO anti-tetanus toxoid standard TE-3 in blocking buffer were used to make a calibration curve. All samples and calibrators were tested in triplicate. The measurement of T2 was performed by placing test strips inside the coil of the relaxometer. All assay steps were carried out at $+37^{\circ} \mathrm{C}$ on an orbital shaker except for the measurement.

\subsection{Agarose Gel Electrophoresis}

Agarose gel electrophoresis was used to study the size of nanoclusters and confirm the presence of a protein coating on their surface [31]. Samples $(5 \mu \mathrm{L}$ per well) were run in $0.5 \%$ agarose gel in $0.5 \times \mathrm{TBE}$ (Tris-borate) buffer, $\mathrm{pH} 8.3$ at 75V. After that, gels were stained with staining solution containing $0.25 \mathrm{~g}$ Coomassie Brilliant Blue R250 in $100 \mathrm{~mL}$ of fixing solution: methanol:acetic acid:water $=4: 1: 4$ and destained with fixing solution. 


\subsection{Protein Corona Study}

In these experiments, Fe@C-NH $2 /$ Protein/Str conjugates were used without stabilizers (1\% BSA and $20 \%$ glycerol), because they can interfere with the test results. The detailed preparation of the conjugates for these experiments is described in the Supporting Information. Different volumes of Fe@C-NH 2 /BSA/Str, Fe@C-NH $2 /$ Casein/Str, Fe@C-NH $2 /$ Gelatin B/Str, and Fe@C-NH $/$ Gelatin A/Str suspensions containing $100 \mu \mathrm{g}$ of nanoclusters were centrifuged for $90 \mathrm{~min}$ at $10,000 \times g$. The supernatant was removed, and $100 \mu \mathrm{L}$ of whole human serum or plasma (pooled serum/plasma from several donors) was added to achieve a final concentration of nanoclusters of $1 \mathrm{mg} / \mathrm{mL}$. To study protein adsorption on the noncoated aminated nanoparticles, $10 \mu \mathrm{L}$ of $10 \mathrm{mg} / \mathrm{mL}$ Fe@C-NH 2 was mixed with serum/plasma without prior centrifugation. The nanoparticles or nanoclusters were sonicated for $1 \mathrm{~s}$ (30\% amplification, $3 \mathrm{~mm}$ probe), vortexed and kept on a rotator in a thermostat at $+37^{\circ} \mathrm{C}$ for $1 \mathrm{~h}$. The fact that ultrasound can damage biopolymers is known [32], thus, we preliminarily confirmed that centrifugation and sonication did not affect the size and zeta potential of the nanoclusters. Unbound proteins were removed by washing with $1 \mathrm{~mL}$ PBS three times with centrifugation at 20,000× $g$ for $15 \mathrm{~min}$. The sedimented nanoclusters were mixed with $20 \mu \mathrm{L}$ of sample buffer $(0.5 \mathrm{M}$ Tris- $\mathrm{HCl} \mathrm{pH}$ $6.8,5 \% \beta$-mercaptoethanol, 10\% SDS, 50\% Glycerol, and 0.1\% bromophenol blue), heated for 5 min at $+95{ }^{\circ} \mathrm{C}$ and sonicated as described above. Ten microliters were loaded into the wells containing a $10 \%$ polyacrylamide gel, and then, the samples were run at $100 \mathrm{~V}$ per gel in Tris- $\mathrm{HCl}$ buffer until the proteins neared the end of the gel. The quantification of adsorbed proteins was carried out as follows. The samples were prepared in the same way except the proteins were eluted using $50 \mu \mathrm{L}$ PBS containing $0.025 \%$ SDS and $4 \mathrm{M}$ urea with heating $\left(+95^{\circ} \mathrm{C}, 5 \mathrm{~min}\right)$; the urea and SDS in mentioned concentrations do not interfere with the Bradford assay according to the manufacturer. The eluted serum proteins were separated by centrifugation $(10,000 \times g, 15 \mathrm{~min})$, and then, the protein concentration was determined by the Bradford assay ( $5 \mu \mathrm{L}$ of undiluted sample $+250 \mu \mathrm{L}$ Bradford reagent) using BSA to obtain a calibration curve. Samples without the addition of serum were used as a control. The concentrations of eluted proteins in the control samples were subtracted from those of the test samples. Three replicates were made for both test and control samples.

\subsection{Thermal Stability of Nanoclusters}

Forty microliters of Fe@C-NH$/$ Protein/G, supplemented with 1\% BSA, 20\% glycerol and 6 mM glycine, was incubated at temperatures ranged from +40 to $+100{ }^{\circ} \mathrm{C}$ in a dry block thermostat for $60 \mathrm{~min}$. The samples were diluted to 1:500 in PBS for the dynamic light scattering (DLS) measurements. Three replicates were made for each sample. The control samples were kept at room temperature throughout the experiment.

\subsection{UV-VIS Spectrophotometry}

Suspensions of Fe@C-NH$/$ Protein/Str in PBS without stabilizers (BSA, glycine, and glycerol) were diluted in PBS, and their spectra were registered using PBS as a blank. Fe@C-NH 2 was diluted in $0.1 \mathrm{M}$ acetic buffer at $\mathrm{pH} 4$ and measured against this buffer.

\subsection{Thermogravimetric Analysis}

A total of $200 \mu \mathrm{L}$ Fe@C-NH 2 and Fe@C-NH$/$ BSA/Str samples were dried at $100{ }^{\circ} \mathrm{C}$ and placed in the TGA furnace. The measurement was carried out under air at a heating rate of $10 \mathrm{~K} \cdot \mathrm{min}^{-1}$ from 25 to $1000{ }^{\circ} \mathrm{C}$.

\subsection{Dynamic Light Scattering (DLS)}

The zeta potential and mean hydrodynamic diameter of the nanoclusters were measured by dynamic light scattering. 
For size measurements, the samples were diluted to 1:500 (3 $\mu \mathrm{L}$ of nanoclusters suspension + $1500 \mu \mathrm{L}$ of buffer) in buffers, which were preliminarily filtered through a polyethersulfone syringe filter with an average pore size of $0.2 \mu \mathrm{m}$ to remove dust, and pipetted into plastic cuvettes $(12 \times 12 \mathrm{~mm})$. Measurements were performed at a scattering angle of $173^{\circ}$ in auto mode. A general purpose model was used to fit the data. The intensity-weighted size (main peak) is reported throughout the article unless otherwise stated.

For the zeta potential measurements, samples were diluted to 1:100 in deionized water $(7 \mu \mathrm{L}$ of nanoclusters suspension $+700 \mu \mathrm{L}$ of water) in the same cuvettes. The measurements were performed in auto mode using a Dip Cell electrode (Malvern, UK). All measurements were done in triplicate.

\subsection{Atomic Force Microscopy (AFM)}

The samples of Fe@C-NH 2 /Protein/Str without stabilizers (BSA, glycerol, and glycine) were diluted with water to $10 \mu \mathrm{g} / \mathrm{mL}$, and then, a drop of the sample suspension was placed onto a microscopic glass slide and dried at room temperature for 30-40 min.

\subsection{Colloidal Stability of Nanoclusters}

The assessment of colloidal stability utilized DLS, and the following buffers were used: $0.1 \mathrm{M}$ acetate buffer ( $\mathrm{pH} 4$ and 5), $0.05 \mathrm{M}$ sodium phosphate buffer ( $\mathrm{pH} \mathrm{6,} \mathrm{7,} \mathrm{and} \mathrm{8),} 0.1 \mathrm{M}$ sodium borate buffer ( $\mathrm{pH} 9$ and 10). The ionic strength was adjusted to $0.15,0.5$, and $2 \mathrm{M}$ using $\mathrm{NaCl}$. All buffers were filtered through $0.2 \mu \mathrm{m}$ polyethersulfone syringe filters and contained $0.1 \%$ sodium azide as a preservative. The samples of Fe@C-NH $\mathrm{N}_{2} /$ Protein/G were diluted to $20 \mu \mathrm{g} / \mathrm{mL}$ for the final volume of $750 \mu \mathrm{L}$ in disposable plastic cuvettes. Three independent samples were prepared for each condition tested. After agitation for $60 \mathrm{~min}$ at room temperature, the size of the nanoclusters was measured by DLS. Then, the cuvettes with samples were left in a humidified chamber at room temperature, and repeated measurements were made in $24 \mathrm{~h}$.

The colloidal stability was also assessed by NMR relaxometry. The samples of Fe@C-NH $/$ Protein/G were diluted to $10 \mu \mathrm{g} / \mathrm{mL}$ in $500 \mu \mathrm{L}$ of the buffer, and then, $100 \mu \mathrm{L}$ samples were added to the wells of a 96-well polystyrene plate and placed inside the relaxometer's coil. The buffers and time points were the same.

\subsection{Storage Stability of Protein-Coated Nanoclusters}

The samples of Fe@C-NH $2 /$ Protein/G in PBS with 1\% BSA, 20\% glycerol and $6 \mathrm{mM}$ glycine were stored at +4 and $+37^{\circ} \mathrm{C}$ (one sample per conjugate). Their hydrodynamic diameter was monitored throughout one month. The conjugates were diluted to 1:350 in $750 \mu \mathrm{L}$ of filtered PBS. The size was measured in triplicate: three independent dilutions of each sample.

Samples of Fe@C-NH $\mathrm{N}_{2} /$ Protein/Str conjugates from the size-tuning study were stored at $+4{ }^{\circ} \mathrm{C}$ for 3-4 months, and their size was measured in the same way.

\subsection{Stability of Nanoclusters in Complex Media}

Red wine, orange juice, beer, and milk were purchased from the local supermarket. Pooled blood serum/plasma from three healthy individuals was thawed and centrifuged at 10,000 $\mathrm{g}$ for $15 \mathrm{~min}$ to remove aggregates. Fe@C-NH $2 /$ Protein/Str and Fe@C-NH $/$ Protein/G were diluted to $10 \mu \mathrm{g} / \mathrm{mL}$ in $500 \mu \mathrm{L}$ of each medium, and then, $100 \mu \mathrm{L}$ samples were added into the wells of a 96-well polystyrene plate and placed inside the relaxometer's coil. Measurements were taken immediately upon the addition of nanoclusters and then after 1 and $5 \mathrm{~h}$. The samples were kept at room temperature throughout the study. 


\subsection{Stability of Nanoclusters to Proteolytic Digestion}

The samples of Fe@C-NH $\mathrm{N}_{2} /$ Protein/Str without stabilizers (BSA, glycerol, and glycine) were diluted to $10 \mu \mathrm{g} / \mathrm{mL}$ with PBS (control samples) or with PBS containing $100 \mu \mathrm{g} / \mathrm{mL}$ of trypsin (test samples). The samples were kept at $+37^{\circ} \mathrm{C}$ in Eppendorf tubes (three tubes for each type of protein coating) in a dry block thermostat for $24 \mathrm{~h}$. The size of the nanoclusters in test samples was measured from 5 to $30 \mathrm{~min}$ after the initial mixture and then after 1,2, and $24 \mathrm{~h}$; the control samples were measured after 2 and $24 \mathrm{~h}$.

\subsection{Determination of Nanoparticles' Relaxivity}

The relaxation measurements were carried out using the homemade portable NMR relaxometer. The magnetic field was approximately $0.1 \mathrm{~T}$; the operating frequency of the device was $4.317 \mathrm{MHz}$. The relative inhomogeneity of the magnetic field in the operating volume of the magnetic system (diameter of $10 \mathrm{~mm}$ and height of $10 \mathrm{~mm}$ ) did not exceed $10^{-4}$. The spin-spin relaxation time (T2) was measured using the Carr-Purcell-Meiboom-Gill (CPMG) pulse sequence with echo spacing TE $=1 \mathrm{~ms}$. Serial 10-fold dilutions of the magnetic nanoclusters were prepared. The starting concentration of the magnetic nanoclusters was approximately $0.02-0.03 \mathrm{mg} / \mathrm{mL}$. After dilution, the nanocluster suspension was sonicated for $10 \mathrm{~s}$ (an immersion-type probe was used). Then, $100 \mu \mathrm{L}$ of suspension was placed in a clean well of a 96-well culture plate (Thermo Fischer Scientific). The cell was placed in an axial measuring coil of the relaxometer. A linear relationship between relaxivity and the concentration of nanoclusters indicated the absence of agglomeration during the measurement.

\section{Results and Discussion}

\subsection{Influence of $p H$, Ionic Strength, and Protein-to-Nanoparticle Ratio on the Size of Protein-Coated Nanoclusters}

Conjugates of magnetic nanoparticles with proteins were synthesized using the following strategy. Fe@C Powder with a mean size of approximately $6 \mathrm{~nm}$ [33] was aminated. The aminated iron-carbon nanoparticles ( $\mathrm{Fe} @ \mathrm{C}-\mathrm{NH}_{2}$ ) were added to aqueous protein solutions. Two simultaneous processes occurred: a $\mathrm{pH}$-dependent aggregation of $\mathrm{Fe} @ \mathrm{C}-\mathrm{NH}_{2}$ and stabilization of aggregates by protein molecules (Fe@C-NH $\mathrm{N}_{2} /$ Protein). The formed surface protein layer was cross-linked with glutaraldehyde and then desired recognition molecules: streptavidin (Fe@C- $\mathrm{NH}_{2} / \mathrm{Protein} / \mathrm{Str}$ ) or protein $\mathrm{G}\left(\mathrm{Fe} @ \mathrm{C}-\mathrm{NH}_{2} /\right.$ Protein/G) was attached via the reaction of primary amines with carbonyl groups (Figure 1). It should be noted that cross-linking stabilizes nanoclusters, and their size depends only on the coating conditions.

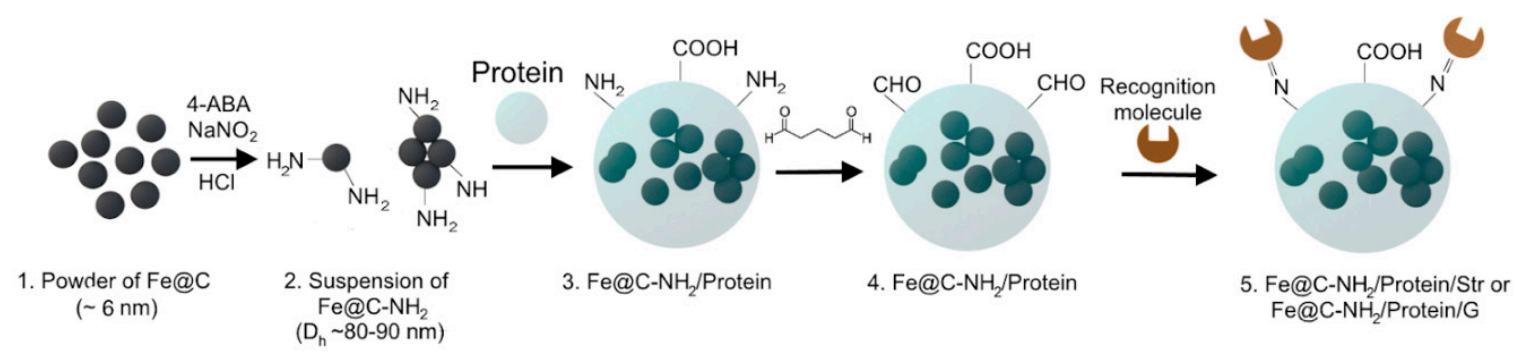

Figure 1. Synthesis of Fe@C-NH $2 /$ Protein/Str and Fe@C-NH $2 /$ Protein/G. 4-ABA-4-aminobenzylamine.

In our previous study, we demonstrated that variations in $\mathrm{pH}$ could be applied to tune the size of BSA-coated nanoclusters [33]. Here, we investigated the influence of coating conditions ( $\mathrm{pH}$, ionic strength, protein-to-nanoparticle mass ratio and sonication time) on the interaction between different proteins (casein, BSA, and gelatins) and $\mathrm{Fe} @ \mathrm{C}-\mathrm{NH}_{2}$ to obtain protein-coated nanoclusters of the desired size. Aminated nanoparticles were coated with proteins under a variety of conditions: $\mathrm{pH}$ ranging from 4 to 9 , ionic strength ranged from 0.01 to 0.5 , and protein-to-nanoparticle mass ratios from 10:1 
to 1.25:1. The size of nanoclusters was measured in PBS after the glutaraldehyde cross-linking of the protein layer.

In our experiments, the size of nanoclusters resulted from a trade-off between the aggregation of Fe@C-NH $\mathrm{NH}_{2}$ at $\mathrm{pH}>4$ and the protein stabilization of Fe@C-NH 2 aggregates. Fe@C-NH $\mathrm{N}_{2}$ is stable at pH 4 [33] (see the zeta potential of Fe@C- $\mathrm{NH}_{2}$ in Figure S2) and aggregates slowly at pH 5 and 9, while at neutral $\mathrm{pH}$, immediate aggregation occurs. Generally, a slight increase in size was observed when the coating was performed at $\mathrm{pH} 6-8$; this effect was more pronounced for gelatin B (Figures S3-S6). At high ionic strength, only the highest protein-to-nanoparticle ratios provided stability to the nanocomposites at $\mathrm{pH}$ between 6 and 8 . The increase in ionic strength led to the overall growth of the nanoclusters' size and polydispersity. Interestingly, in comparison with BSA and especially casein, the gelatin B coating efficiently stabilized nanoclusters, even at the highest salt concentration, without a sharp increase in the mean diameter. In total, a decrease in the protein-to-nanoparticle mass ratio caused the enlargement of the nanoclusters, especially when BSA was used. It is known that van der Waals forces, hydrogen bonding, Coulombic forces, and hydrophobic interactions are the main driving mechanisms of protein adsorption on nanoparticles [34]. Apparently, Coulombic forces possess a dominant role in the stabilization of Fe@C- $\mathrm{NH}_{2}$ by casein, because this protein provides good stability in solutions with lower salt concentrations. In contrast, the impact of the hydrophobic force prevails in the case of gelatin B. Gelatin A showed a poor ability to stabilize aminated nanoparticles even at the lowest ionic strength. Therefore, media with higher salt concentrations were not tested.

Sonication power is another parameter that can be used to manipulate the size of protein-coated nanoparticles [35]. Prolonged sonication allows up to a two-fold decrease in particles' size and polydispersity (Figure S7).

In further experiments, we adjusted the synthesis conditions to obtain protein-coated magnetic nanoclusters with various sizes to explore their stability, relaxivity, and functional activity in the solid phase NMR-assay.

\subsection{Synthesis and Relaxivity Study of Protein-Coated Nanoclusters with Tunable Size}

The size of magnetic nanoparticles affects their $\mathrm{r} 2$ relaxivity [13] and may be critical for different aspects of immunoassays. Wang et al. demonstrated that the migration rate of magnetic nanoparticles inside the lateral flow test strip depends on their diameter, and in turn, has a dramatic impact on the assay duration and sensitivity [36]; furthermore, smaller magnetic nanoparticles provide a more efficient magnet-assisted pre-analytical enrichment of samples [3]. The application of larger nanoparticles and even microparticles in homogeneous NMR sensors can improve the lower limit of detection [37].

We prepared nanoclusters of iron-carbon magnetic nanoparticles coated with casein, BSA and gelatin B and conjugated with streptavidin. For each type of coating, three groups of conjugates were obtained: "small", "medium", and "large". We should note that the size of each group depended on the coating type, e.g., we were unable to prepare Fe@C- $\mathrm{NH}_{2} /$ Gelatin B/Str with a diameter less than $140 \mathrm{~nm}$; at the same time, 100-110 nm nanoclusters can be easily obtained when the BSA coating is used. Despite the difference in absolute diameters, both conjugates were designated as "small". Moreover, various streptavidin-to-nanoparticle ratios were used for all groups: from 10:1 to 160:1 ( $\mu \mathrm{g}: \mathrm{mg}$ ), and in total, 45 conjugates were prepared. The main characteristics of conjugates are summarized in Table 1. Detailed information about the size, polydispersity, and zeta potential of each synthesized conjugate can be found in Figures S8, S9 and Table S1. The size of Fe@C-NH $\mathrm{N}_{2} / \mathrm{Protein} / \mathrm{Str}$ was measured by DLS, while the migration of nanoclusters in agarose gel was used to characterize and compare the nanoclusters (Figure S10, lanes 1, 6-14). The mobility of nanoclusters depends on their size and zeta potential; the nanocluster migration pattern confirms the results of DLS: casein- and BSA-coated nanoclusters with the highest zeta potentials moved strongly toward the positive electrode. "Large" nanoclusters hardly entered the gel, even 30 min after the start. 
Table 1. Properties of conjugates prepared during size-tuning experiments.

\begin{tabular}{|c|c|c|c|c|c|c|c|c|c|}
\hline \multirow{2}{*}{$\begin{array}{c}\text { Coating } \\
\text { Group }\end{array}$} & \multicolumn{3}{|c|}{$\mathrm{Fe} @ \mathrm{C}-\mathrm{NH}_{2} / \mathrm{BSA} / \mathrm{Str}$} & \multicolumn{3}{|c|}{$\mathrm{Fe} @ \mathrm{C}-\mathrm{NH}_{2} /$ Casein/Str } & \multicolumn{3}{|c|}{$\mathrm{Fe} @ \mathrm{C}-\mathrm{NH}_{2} /$ Gelatin B/Str } \\
\hline & "Small" & "Medium" & "Large" & "Small" & "Medium" & "Large" & “Small” & "Medium" & “Large" \\
\hline$D_{h, n m}$ & $114-121$ & $172-186$ & $211-233$ & $114-131$ & 194-198 & $235-274$ & $142-160$ & $212-243$ & 279-309 \\
\hline PdI & $0.188-0.208$ & $0.158-0.175$ & $0.247-0.258$ & $0.178-0.201$ & $0.132-0.169$ & $0.202-0.243$ & $0.211-0.248$ & $0.200-0.260$ & $0.227-0.257$ \\
\hline Relaxivity, $1 / \mathrm{mM}^{-1} \times \mathrm{s}^{-1}$ & $234-265$ & $262-322$ & $186-230$ & $310-354$ & $318-340$ & $303-345$ & $266-306$ & $296-377$ & $282-324$ \\
\hline
\end{tabular}

Note: Severe aggregation was observed in the conjugate Fe@C-NH$/$ Gelatin B/Str synthesized at a streptavidin-tonanocluster ratio of 10:1 immediately after the synthesis, and this conjugate was excluded from our study.

Interestingly, large nanoclusters can be seen in the wells in which "medium" nanoclusters were loaded (Figure S10, lanes 6, 10, and 13). Moreover, "medium" nanoclusters distributed more diffusely along the path of migration compared with that of "small" nanoclusters, indicating the presence of a portion of large nanoclusters, and hence, a high polydispersity. However, according to DLS, the "medium" nanoclusters possess the lowest polydispersity. Moreover, it is well known that DLS overestimates the hydrodynamic diameter and shows a high polydispersity when large aggregates are present in the sample. A possible explanation is that nanoclusters larger than 170-180 $\mathrm{nm}$ do not enter the gel, while the smaller ones penetrate it. A diffuse band of nanoclusters represents those with a size between 130 and $170 \mathrm{~nm}$, which are also present in the samples. Coomassie Blue staining of the protein-coated nanoclusters after gel-electrophoresis was performed to confirm the presence of a protein on the surface of Fe@C- $\mathrm{NH}_{2}$; unfortunately, the nanoclusters are too dark to detect any color change.

The functional activity of each Fe@C- $\mathrm{NH}_{2} /$ protein/Str conjugate was examined in the solid phase NMR-assay. Biotinylated BSA was spotted on nitrocellulose test-strips in 10-fold dilutions, then, diluted conjugates were added, and the relaxation time depending on the number of nanoclusters attached to nitrocellulose was measured (Figure S11). Thus, we confirmed the applicability of the synthesized nanoclusters for NMR-assays; calibration curves were obtained for each conjugate (Figure S12). The type of coating, size of nanoclusters, and streptavidin-to-nanocluster ratio had a negligible effect on the shape of the calibration curves.

The protein coating of the magnetic nanoparticles can enhance their $\mathrm{r} 2$ relaxivity [13]. Recently, this effect was demonstrated for casein [38] and BSA [39,40]. Inspired by the above, we studied the r2 relaxivity of Fe@C-NH $\mathrm{N}_{2} / \mathrm{Protein} / \mathrm{Str}$ of different sizes. The relaxivity values of Fe@C-NH $\mathrm{N}_{2} / \mathrm{Casein} / \mathrm{Str}$ and Fe@C- $\mathrm{NH}_{2} /$ Gelatin $\mathrm{B} / \mathrm{Str}$ are independent of their size and are higher in comparison with that of Fe@C-NH $/$ BSA/Str (Figure 2). Moreover, the r2 relaxivity of Fe@C- $\mathrm{NH}_{2} / \mathrm{BSA} / \mathrm{Str}$ was even lower than that of the parent Fe@C- $\mathrm{NH}_{2}$. We suggested that the different structures of the $\mathrm{Fe} @ \mathrm{C}-\mathrm{NH}_{2} /$ Protein/Str nanoclusters can be the reason for the differences in their $\mathrm{r} 2$ relaxivity values. The study of Fe@C-NH $/$ /Protein/Str using transmission electron microscopy showed that individual Fe@C-NH ${ }_{2}$ particles are more uniformly distributed (Figure 3a) in the Fe@C- $\mathrm{NH}_{2} / \mathrm{Casein} / \mathrm{Str}$ in comparison with Fe@C-NH $\mathrm{N}_{2} /$ Gelatin B/Str (Figure 3c) and especially Fe@C-NH $\mathrm{N}_{2} / \mathrm{BSA} / \mathrm{Str}$ (Figure 3b). Therefore, we suggest that the uniformity of the Fe@C- $\mathrm{NH}_{2}$ nanoparticle distribution inside the nanocluster, rather than the size of the Fe@C- $\mathrm{NH}_{2} /$ Protein/Str nanocluster, affects the nanoclusters' r2 relaxivity. Roca et al. [41] noted that the influence of magnetic nanoparticles on the proton relaxation rate is determined by not only the properties of an individual particle (saturation magnetization, nanoparticle size) but also how the magnetic nanoparticles are distributed inside their agglomerate. This effect is because the agglomerates of nanoparticles located inside the conjugate will be inaccessible to protons. In contrast, a uniform distribution of noninteracting magnetic nanoparticles inside a protein conjugate will make the greatest contribution to relaxation, provided that the medium separating them (in our case, protein) is permeable to protons. 


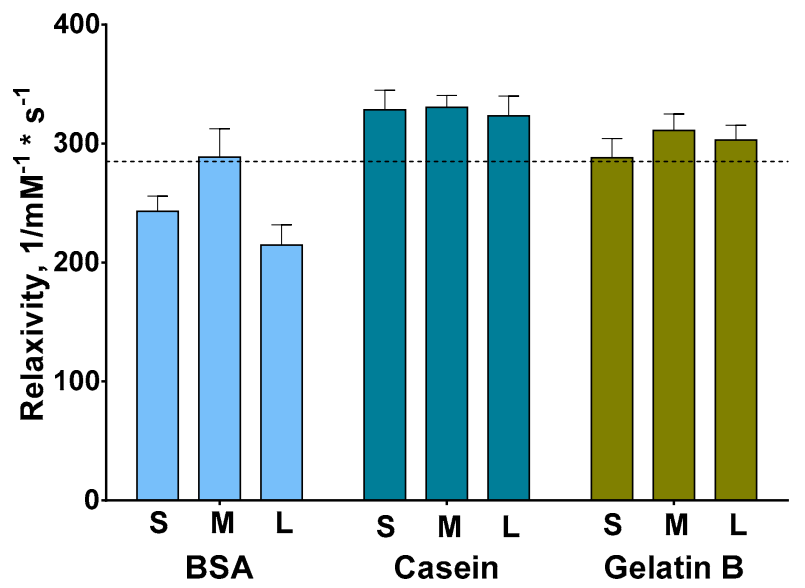

Figure 2. Relaxivity of conjugates with different sizes and coating types, $n=5$, mean $\pm \mathrm{SD}$. Letters "S", " $\mathrm{M}$ ", and "L" indicate "small", "medium", and "large" nanoclusters, respectively; the dashed line indicates the relaxivity of the parent Fe@C- $\mathrm{NH}_{2}\left(2851 / \mathrm{mM}^{-1} \times \mathrm{s}^{-1}\right)$. Conjugate Fe@C-NH$/ \mathrm{Nelatin}_{2}$ $\mathrm{B} / \mathrm{Str}$ with highest relaxivity was excluded when mean relaxivity values were calculated.
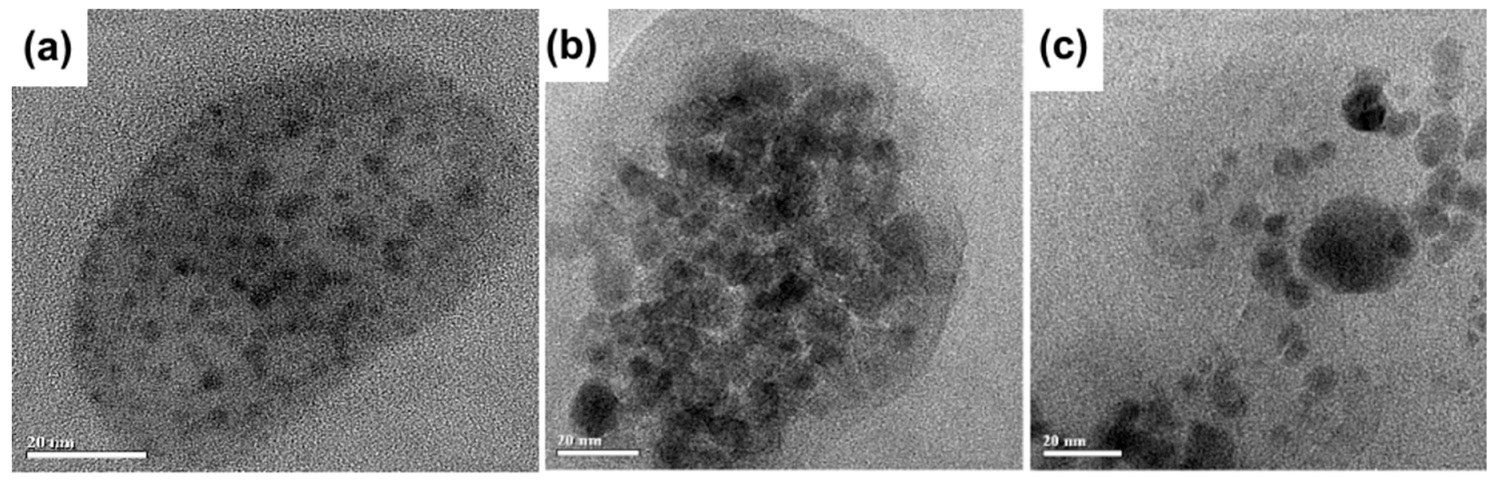

Figure 3. TEM images of Fe@C-NH $\mathrm{NH}_{2} / \mathrm{Casein} / \mathrm{Str}(\mathbf{a})$, Fe@C-NH $2 / \mathrm{BSA} / \mathrm{Str}$ (b), and Fe@C-NH $/ \mathrm{NH}_{2}$ Gelatin B/Str (c). Scale bars are $20 \mathrm{~nm}$.

Thus, Fe@C- $\mathrm{NH}_{2}$ nanoparticles are distributed nonuniformly in the protein matrix, affecting the Fe@C- $\mathrm{NH}_{2} /$ Protein/Str relaxivity. The uniformity of distribution, in turn, depends on the nature of the protein and the procedure for the synthesis of Fe@C- $\mathrm{NH}_{2} / \mathrm{Protein} / \mathrm{Str}$. It should be noted that despite the Fe@C-NH 2 /Protein/Str from each size group ("small", "medium", and "large") being prepared using the same portion of Fe@C- $\mathrm{NH}_{2} /$ Protein, the resulting relaxivity varied significantly (in the range of $801 / \mathrm{mM}^{-1} \times \mathrm{s}^{-1}$ ) between conjugates from the same size groups (Table 1, Table S1), reflecting the significant influence of fluctuations in the synthesis procedure on relaxivity. A further increase in the relaxation characteristics can be achieved by selecting such synthesis conditions that ensure the uniform distribution of individual nanoparticles in the protein shell and prevent the formation of their aggregates. It must be emphasized that the relaxivity of the synthesized nanoconjugates is comparable to the relaxivity of MRI contrasts based on iron oxides [23].

\subsection{Characterization of Nanoclusters}

The structure and morphology of nanoclusters were assessed using atomic force microscopy (AFM) and TEM. As shown in Figure 4a-d, Fe@C-NH $2 /$ Protein/Str has a nearly round shape. We did not assess the mean size of conjugates by microscopy because aggregates were produced during the sample preparation. The mean hydrodynamic diameters (intensity of the main peak) were determined by DLS, and they are reported throughout the article. The presence of proteins on the surface of 
Fe@C-NH $2 /$ Protein/Str and Fe@C-NH $2 /$ protein/G was confirmed by UV-VIS spectroscopy; there is a pronounced peak at 190-250 $\mathrm{nm}$, indicating the successful functionalization (Figure $4 \mathrm{f}-\mathrm{i}$ ).

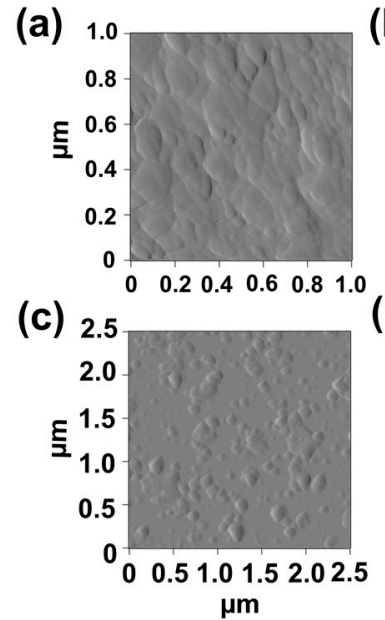

(e)

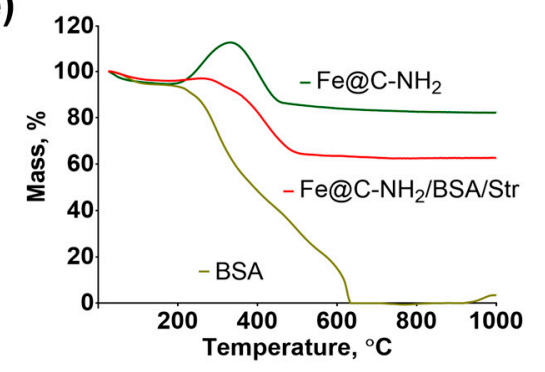

(f)

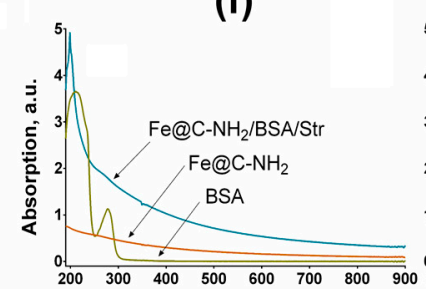

(h)
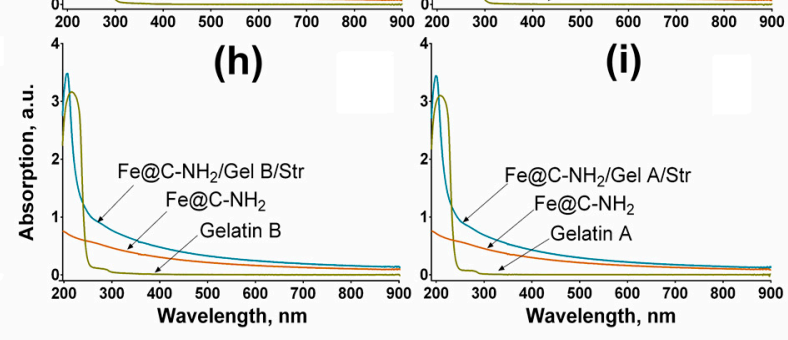

(j)

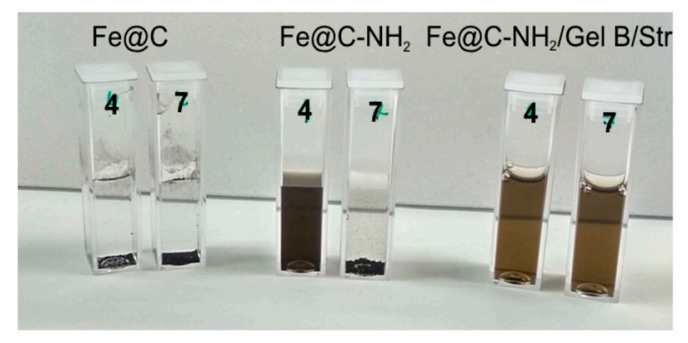

Figure 4. Properties of nanoclusters coated with different proteins. Upper left: atomic force microscopy (AFM) images of nanoclusters coated with different proteins: (a) BSA, (b) casein, (c) gelatin A, and (d) gelatin B; lower left: (e) thermogravimetric analysis (TGA) curves of Fe@C-NH $\mathrm{N}_{2}$, BSA and Fe@C-NH $\mathrm{N}_{2} / \mathrm{BSA} / \mathrm{Str}$ in airflow; upper right: UV-Vis spectra of Fe@C-NH $\mathrm{N}_{2}, \mathrm{Fe} @ \mathrm{C}-\mathrm{NH}_{2} / \mathrm{Protein} / \mathrm{Str}$ and proteins: (f) BSA, (g) casein, $(\mathbf{h})$ gelatin B, and (i) gelatin A; and lower right: (j) stability of Fe@C, Fe@C-NH ${ }_{2}$, Fe@C-NH $/$ Gelatin B/Str in buffers with pH 4 and 7.

Moreover, the changes in electrophoretic mobility (Figure S10, lanes 1-5) and dispersibility at different $\mathrm{pH}$ (Figure 4j) also prove the presence of the protein coating. Aminated iron-carbon nanoparticles immediately aggregate in the electrophoresis buffer, while the protein-coated nanoclusters enter the gel and move toward the positive electrode. Fe@C sedimented at pH 4 and 7, the Fe@C- $\mathrm{NH}_{2}$ are stable at $\mathrm{pH} 4$ because of the electrostatic repulsion between protonated amino groups, but this is not the case at $\mathrm{pH} 7$. Gelatin-coated nanoclusters are stable at both $\mathrm{pH} 4$ and 7, and this is opposite to the behavior of casein- and BSA-coated ones, whose size remains unchanged at $\mathrm{pH} 7$ but slowly grows at $\mathrm{pH} 4$ (see Section 3.6).

Thermogravimetric analysis (TGA) was used to determine the concentration of Fe in Fe@C- $\mathrm{NH}_{2}$ and confirm the presence of a protein coating. The TGA curves of Fe@C-NH $2, B S A$, and Fe@C-NH $-\mathrm{BSA} / \mathrm{Str}$ (Figure 4e) showed that below $180^{\circ} \mathrm{C}$ the weight loss of all samples was quite small (5-7\%) because of the removal of physically and chemically adsorbed water. In the segment from 190 to $330^{\circ} \mathrm{C}$, the TGA curve of Fe@C- $\mathrm{NH}_{2}$ exhibits a gradual weight gain. This weight gain implies that the Fe cores are being slowly oxidized. The data also indicate that Fe@C nanoparticles are securely stable below $190{ }^{\circ} \mathrm{C}$ in air.

Above $330^{\circ} \mathrm{C}$, the full oxidation to $\mathrm{Fe}_{2} \mathrm{O}_{3}$ occurs, and the weight loss neglects the weight gain due to the oxidation of carbon to $\mathrm{CO}_{2}$. That is, the weight loss between 330 and $800{ }^{\circ} \mathrm{C}$ is recognized as an active chemical reaction in which the graphite phase is oxidized to $\mathrm{CO}_{2}$ gas. The oxidation temperature of the carbon shell in the Fe@C- $\mathrm{NH}_{2}$ nanoparticles is significantly lower than that of carbon nanotubes 
$\left(527-727^{\circ} \mathrm{C}\right)$ and bulk graphite crystals $\left(846^{\circ} \mathrm{C}\right)$; this outcome is ascribed to a mass of lattice defects resulting from the serious bending of the graphite atomic layers. From the TGA data, we calculate that the concentration of the magnetic Fe in a Fe@C- $\mathrm{NH}_{2}$ sample is $68.1 \mathrm{wt} \%$. In contrast to Fe@C- $\mathrm{NH}_{2}$, there was no weight gain when the Fe@C- $\mathrm{NH}_{2} / \mathrm{BSA} / \mathrm{Str}$ nanoclusters were analyzed, evidently due to the presence of the protein coating. The complete degradation of BSA took place in the range from 200 to $640{ }^{\circ} \mathrm{C}$, and only $\mathrm{Fe}_{2} \mathrm{O}_{3}$ remained in the crucible after $650^{\circ} \mathrm{C}$. We calculated that the concentrations of magnetic Fe and BSA in the Fe@C- $\mathrm{NH}_{2} / \mathrm{BSA} / \mathrm{Str}$ nanoclusters were 45.7 and $31.5 \mathrm{wt} \%$, respectively.

\subsection{NMR-Assay of Anti-Tetanus Antibodies}

The protein-coated magnetic nanoclusters were applied to the solid phase NMR-assay of anti-tetanus antibodies. The concentration of antibodies correlates with the protection against tetanus and reflects the efficiency of the vaccination. According to the World Health Organization, the protective threshold of antitoxin concentration is $0.1 \mathrm{IU} / \mathrm{mL}$ [42]. Nitrocellulose test-strips were coated with tetanus toxoid and then treated with antibodies against tetanus toxoid. The antibodies were detected with protein G-conjugated magnetic nanoclusters, which decrease the relaxation of water protons inside the pores of the membrane. Thus, the T2 relaxation time of water protons is proportional to the antibody concentration (Figure 5).
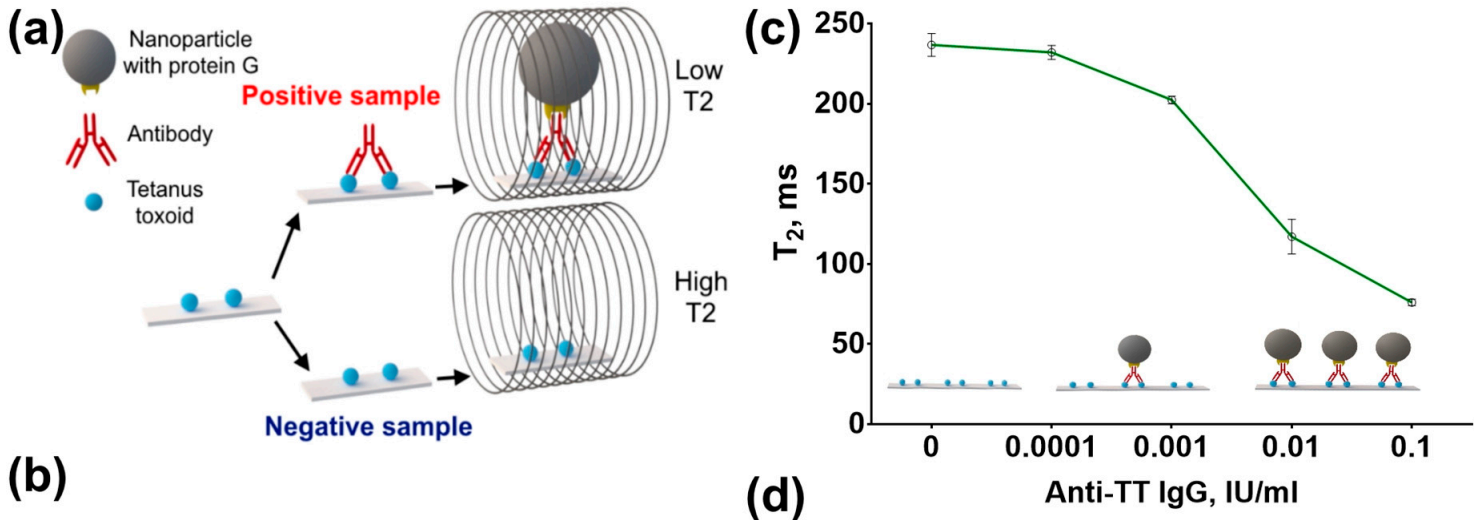

(b)
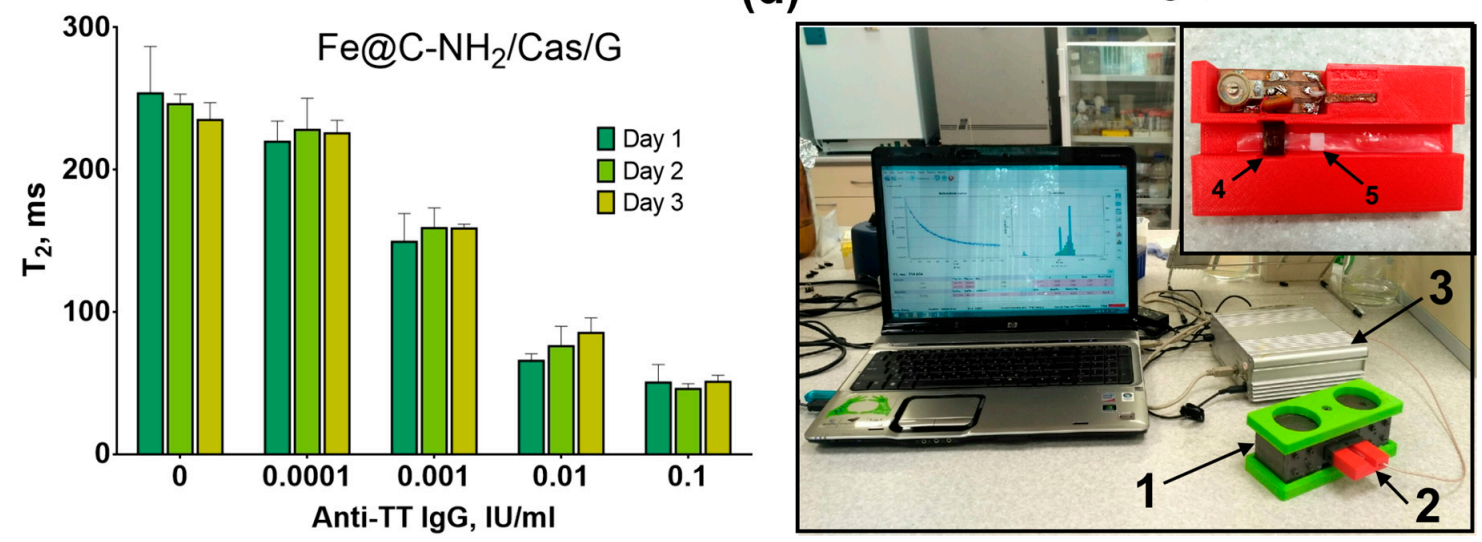

Figure 5. Application of protein-coated magnetic nanoclusters in nuclear magnetic resonance (NMR)-immunoassay of IgG against the anti-tetanus toxoid. (a) the principle of the assay; (b) day-to-day variability of the anti-TT NMR-assay; (c) dose-response curve obtained using Fe@C-NH $\mathrm{N}_{2} / \mathrm{Casein} / \mathrm{G}$; (d) NMR-relaxometer and sample holder (inset): 1-magnet, 2-sample holder, 3-NMR-relaxometer, 4 -radio-frequency coil, and 5-test-strip in plastic envelope.

Regardless of the material used to coat nanoclusters, they were applicable for antibody detection. Fe@C-NH $2 /$ BSA/G and Fe@C-NH $/$ Casein/G provided better analytical sensitivities; however, lower nonspecific signals and steeper slopes of dose-response curves were generated for gelatin-coated nanoclusters (Figure S13). We did not optimize the assay conditions but rather used the same assay 
parameters for all four tested conjugates, and there are clear differences in their performances. Generally, good day-to-day reproducibility of the analysis was obtained for all conjugates. However, significant variation was observed in the blank sample for Fe@C- $\mathrm{NH}_{2} /$ Gelatin A/G (Figure S13). To assess whether the antibody in real samples can be detected, we tested 10 blood serum samples obtained from vaccinated individuals. Fe@C-NH$/ 2$ Casein/G was used in the assay. The lower limit of detection was $0.52 \mathrm{mIU} / \mathrm{mL}$ (blank $+3 \mathrm{SD}$ ), which is less than that of double-antigen ELISA or bead-based multiplex immunoassay (Table 2). Nevertheless, analytical sensitivity of the assay was far less than the protective threshold and allows quantification of anti-TT IgG in unprotected individuals. A good correlation $\left(\mathrm{r}^{2}=0.97\right)$ with the ELISA results was demonstrated. However, the NMR-assay significantly overestimated antibody concentrations, indicating that further optimization is necessary (Figure S14).

Table 2. Comparison of the NMR-assay with anti-TT IgG detection methods described in literature.

\begin{tabular}{|c|c|c|c|c|}
\hline Assay & Label & LOD, mIU/mL & Assay duration, $\mathrm{h}$ & Reference \\
\hline ELISA & horseradish peroxidase & 0.01 & 4 & [43] \\
\hline Multiplex immunoassay & fluorescent beads & 0.01 & 1.25 & [44] \\
\hline Lateral flow assay & gold nanoparticles & 10 & 0.25 & [45] \\
\hline Surface plasmon resonance assay & gold nanoparticles & 5 & 2.15 & [46] \\
\hline ELISA on polymer fibers & horseradish peroxidase & 0.5 & 2.15 & [47] \\
\hline Microfluidic assay & fluorescent dye & 100 & Less than 1 & [48] \\
\hline NMR assay & $\begin{array}{l}\text { carbon-coated iron } \\
\text { nanoparticles }\end{array}$ & 0.52 & $3-4$ & This work \\
\hline
\end{tabular}

\subsection{Thermal Stability Study}

The colloidal stability of magnetic nanoprobes at elevated temperatures is essential for applications in assays based on the isothermal amplification of DNA (e.g., loop-mediated isothermal amplification or rolling circle amplification) [49] or PCR [50], when reaction mixtures can be heated up to $+95^{\circ} \mathrm{C}$. The aggregation of nanoparticles can negatively influence assay performance. Herein, we tested how heating affects the size of protein-coated nanoclusters. The interaction with the nanoparticles and cross-linking enhance the heat stability of proteins [51,52], and vice versa, where protein coatings can protect nanoparticles from heat-induced aggregation [53].

The size of Fe@C-NH $/$ BSA/G was almost the same until $+80{ }^{\circ} \mathrm{C}$; from +80 to $+100{ }^{\circ} \mathrm{C}$, the nanoparticle diameter sharply increased (Figure 6). Meanwhile, the diameter of Fe@C- $\mathrm{NH}_{2} / \mathrm{Casein} / \mathrm{G}$ gradually increased from 132 to $144 \mathrm{~nm}$, but the polydispersity indices of both conjugates did not exceed 0.2 , reflecting good thermal stability. According to [54], irreversible heat denaturation of BSA starts at $+50{ }^{\circ} \mathrm{C}$ and becomes more prominent with increasing temperature; in contrast, casein is an intrinsically unstructured protein with a better heat stability [55]. These differences can explain the nanoclusters' behaviors upon heating. The hydrodynamic diameter of gelatin-B-coated nanoclusters did not change significantly. However, the polydispersity index increased at temperatures of $+70{ }^{\circ} \mathrm{C}$ and higher. The increase in the polydispersity of Fe@C- $\mathrm{NH}_{2} /$ Gelatin $\mathrm{A} / \mathrm{G}$ occurred at $+60^{\circ} \mathrm{C}$ and higher. These data are in agreement with the findings of Bigi et al., demonstrating the denaturation of glutaraldehyde cross-linked gelatin gels at $+70{ }^{\circ} \mathrm{C}$ [51]. In total, the thermal stability of protein-coated nanoclusters is appropriate for the application in homogeneous assays, which require heating. The nanoparticle size increase of 10-30 $\mathrm{nm}$ should not significantly influence the surface-to-volume ratio and relaxivity, especially for the casein and gelatin coatings (see Section 3.2). 

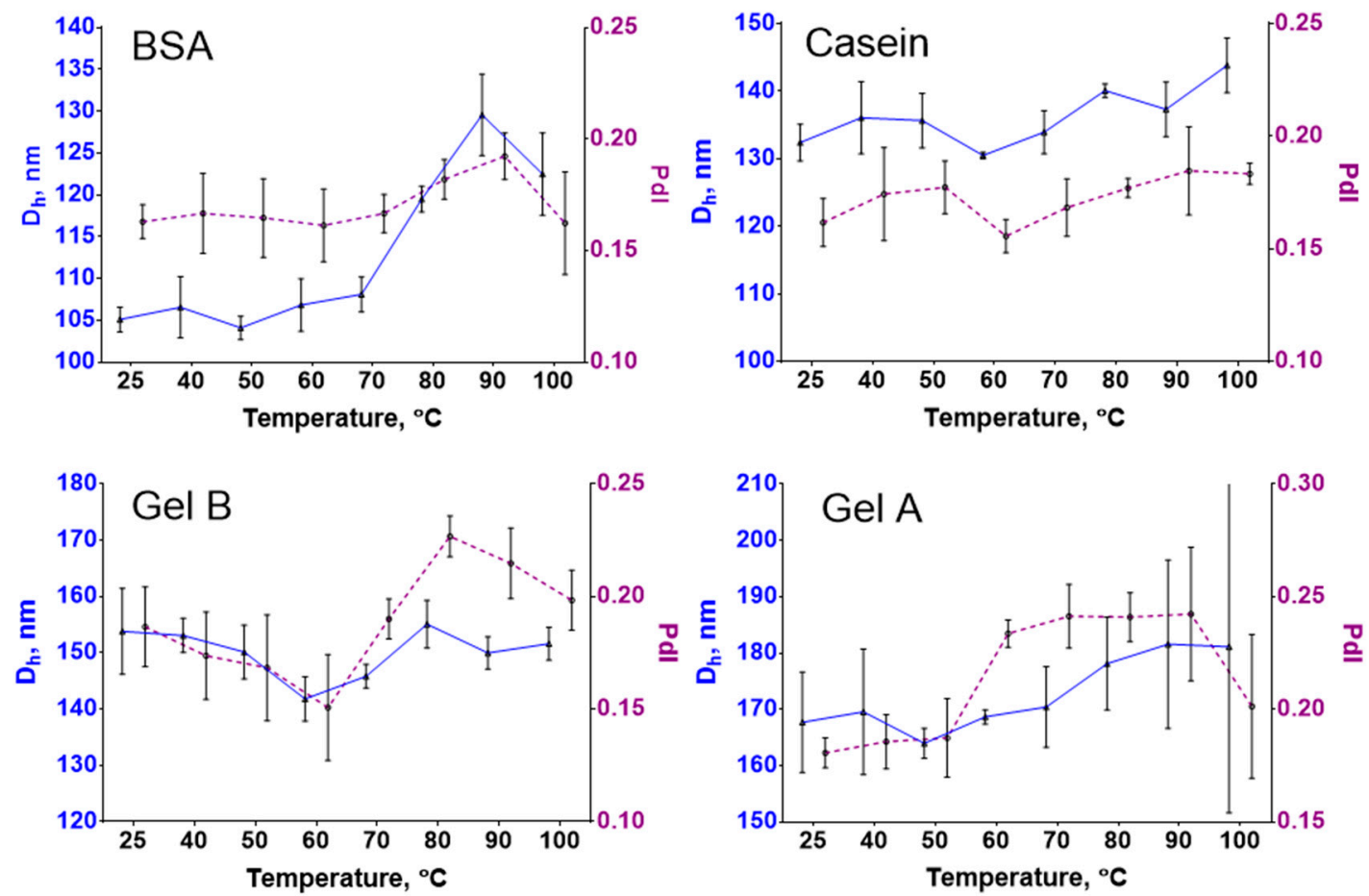

Figure 6. Thermal stability of (BSA) Fe@C-NH $2 / B S A / G$; (Casein) Fe@C-NH $\mathrm{NH}_{2} /$ Casein/G; (Gel B)

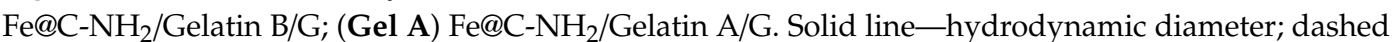
line-polydispersity index, $n=3$, mean \pm SD.

\subsection{Colloidal Stability and Shelf Life}

A resistance to aggregation is an inevitable requirement of nanoconjugates that is necessary for their practical implementation. Nanoparticles should be stable at neutral and near-neutral $\mathrm{pH}$ to be suitable for most of bioanalytical applications. Moreover, for some applications, a stability at extreme $\mathrm{pH}$ or ionic strength, at least short-term, is much needed. Herein, we directly compared the hydrodynamic diameter and polydispersity of magnetic nanoclusters coated with BSA, casein, and gelatins $\mathrm{A}$ and $\mathrm{B}$ after 1 and $24 \mathrm{~h}$ of incubation in buffers with $\mathrm{pH} 4-10$ and a salt concentration from 0.15 to $2 \mathrm{M}$. Two different methods were used: dynamic light scattering and T2 relaxometry. The latter is sensitive to the size of the magnetic nanoclusters because their aggregation results in the growth of T2. This method is semiquantitative rather than quantitative and was only applied to strengthen the results obtained using DLS.

Nanoparticles coated with BSA and casein were stable in solutions at $\mathrm{pH}$ 6-10 when the ionic strength did not exceed $0.5 \mathrm{M}$; however, aggregation was observed at pH 6 in $2 \mathrm{M}$ PBS. A slight growth in the size of casein-coated nanoclusters can be seen after $24 \mathrm{~h}$ of incubation. This growth was more prominent in $2 \mathrm{M}$ solutions, where nanocluster enlargement occurred even at alkaline $\mathrm{pH}$. Importantly, there was no significant aggregation of gelatin-coated nanoclusters at any $\mathrm{pH}$ or ionic strength after $24 \mathrm{~h}$. The increase in ionic strength from 0.15 to $2 \mathrm{M}$ resulted in the overall growth of the nanoclusters' diameter to approx. 20-30 nm, regardless of their coating. We should emphasize the fairly low reproducibility of the DLS measurements. Three technical replicates were prepared for each sample, and in some cases, a significant discrepancy between replicates was observed. Repeated measurements of the same cuvette sometimes gave opposing results (low/high polydispersity). Moreover, sometimes a dramatic decrease in size and polydispersity was observed for repeated measurements of the same replicate after $24 \mathrm{~h}$ of incubation, which is hardly possible. For these reasons, we excluded unreproducible results from the analysis used to prepare the graphs (Figure 7). Furthermore, the short-term stability of conjugates under the same conditions was assessed by T2 relaxometry (Figure 8). The results of the T2 measurements confirmed the previous findings. A significant increase in T2 was observed after the incubation of BSA- and casein-coated 
Fe@C-NH $\mathrm{N}_{2}$ in buffers with acidic $\mathrm{pH}$. The increase in T2 for casein-coated nanoclusters after $24 \mathrm{~h}$ was more prominent than that for Fe@C- $\mathrm{NH}_{2} / \mathrm{BSA} / \mathrm{G}$, especially in solutions with ionic strengths higher than $0.5 \mathrm{M}$. The T2 relaxometry was not sensitive enough to distinguish between the mentioned 20-30 nm size differences caused by the high salt concentration. However, a slight increase in T2 was found for gelatin-coated nanoclusters diluted in buffers with $\mathrm{pH} 4$ and ionic strengths of 0.15 and $0.5 \mathrm{M}$, but not of $2 \mathrm{M}$. Some degree of aggregation of nanoclusters coated with gelatins A and B probably takes place at this $\mathrm{pH}$, but we did not reveal it by DLS.

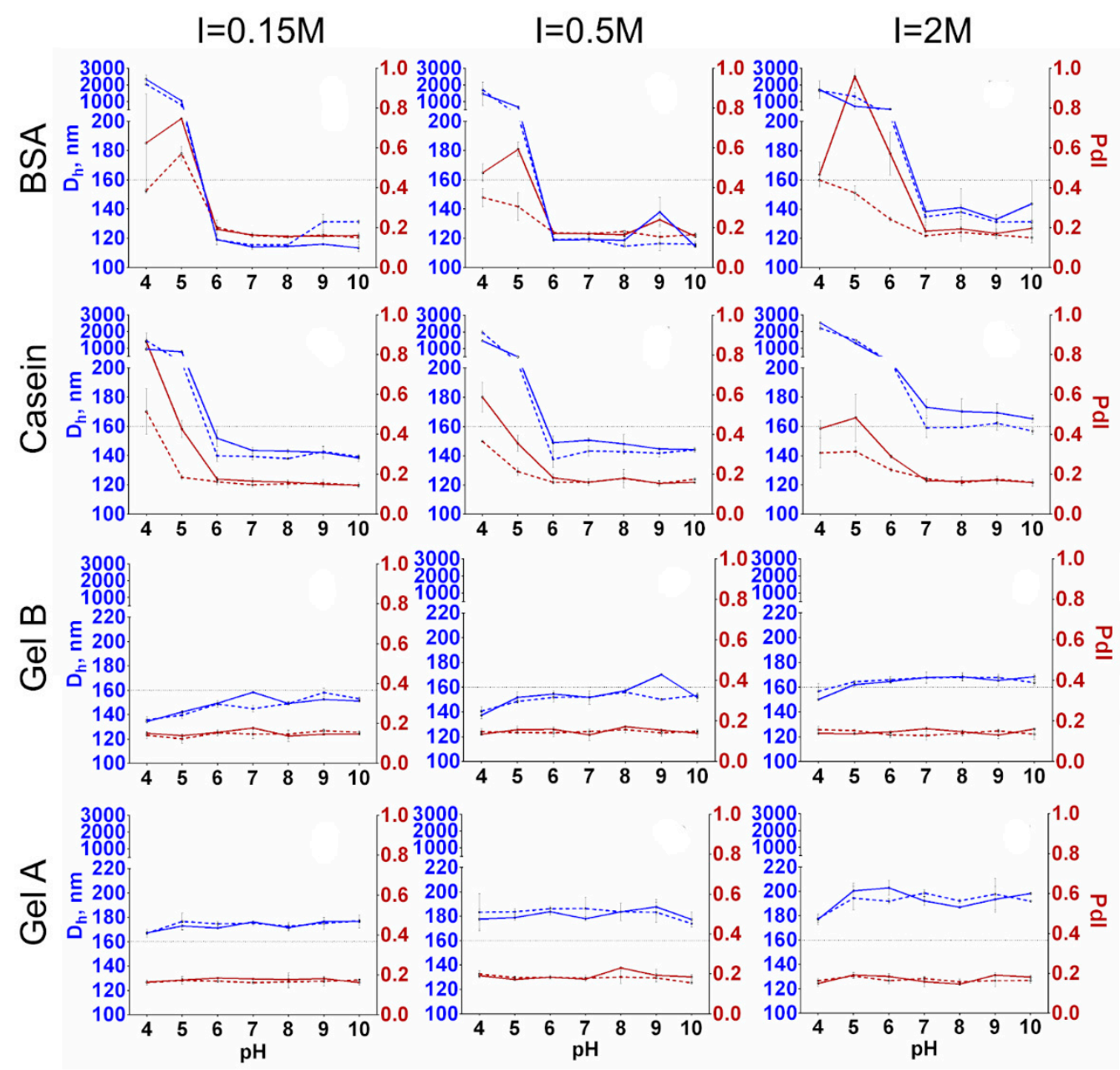

Figure 7. Colloidal stability of Fe@C- $\mathrm{NH}_{2} /$ Protein/G in buffers with different $\mathrm{pH}$ and ionic strength values. Ionic strength values are specified at the top of the figure. "BSA", "Casein", "Gel B", and "Gel $\mathrm{A}^{\prime \prime}$ indicate coating protein. Blue line-hydrodynamic diameter at 0 (dashed line) and $24 \mathrm{~h}$ (solid line); orange line-polydispersity index at 0 (dashed line) and $24 \mathrm{~h}$ (solid line), $n=3$, mean $\pm \mathrm{SD}$.

Our observations are in contradiction with the findings of [56], who demonstrated the aggregation of glutaraldehyde cross-linked gelatin nanoparticles at $\mathrm{pH}$ 5. At the same time, Gaihre et al. [57] and Sivera et al. [58] respectfully obtained suspensions of $\mathrm{Fe}_{3} \mathrm{O}_{4}$ and $\mathrm{Ag}$ nanoparticles coated with gelatin that were stable at a pH range of 2-12. Gaihre et al. synthesized gelatin A- and gelatin B-coated iron oxide nanoparticles that were stable at $\mathrm{pH} 4-8$. A slight sedimentation was observed for gelatin B-encapsulated nanoparticles but not for gelatin A-encapsulated nanoparticles at ionic strengths higher than 0.1 . This result was explained by the more prominent "salting out" of the former provoked by more gelatin B adsorbed on iron oxide nanoparticles [59]. Furthermore, a gelatin A coating prevented gold nanoparticles from aggregation at high ionic strengths [60]. 
Several research groups also studied the stability of casein- and BSA-functionalized nanoparticles. Casein-encapsulated iron oxide nanoparticles were stable at $\mathrm{pH} 2-8$ except for $\mathrm{pH} 4$ [61]. Casein-coated zein nanoparticles were stable at I 0-200 mM and pH 2-9. However, a growth in diameter at $\mathrm{pH} 4$ and 5 was observed [62]. A severe aggregation of casein-coated Ag nanoparticles was observed at $\mathrm{pH}$ lower than the isoelectric point of casein; however, this was not so at $\mathrm{pH} 8-13$, and only a slight aggregation was observed at $\mathrm{pH}$ lower than 8 . While, salt concentrations up to $0.5 \mathrm{M}$ did not induce a change in their size [63]. BSA-coated quantum dot/magnetic nanoparticle composites were stable at ionic strengths up to 0.5 and at $\mathrm{pH} 5-13$ but aggregated at $\mathrm{pH} 3$ and 4 [64]. Zhang et al. demonstrated the good stability of quantum dots coated with BSA at ionic strengths up to $2 \mathrm{M}$ and at $\mathrm{pH}$ ranging from 2-12 with small decreases at 5.6 and 6.1 [65]. BSA-coated magnetic nanoparticles were stable at pH 4-13 except for $\mathrm{pH} 5.6$ and at an ionic strength from $10 \mathrm{mM}$ to $1 \mathrm{M}$ [66]. Gold nanoparticles with a BSA shell were also stable throughout $\mathrm{pH} 1.5-10$ except at $\mathrm{pH}$ near 4.5-5 [67].
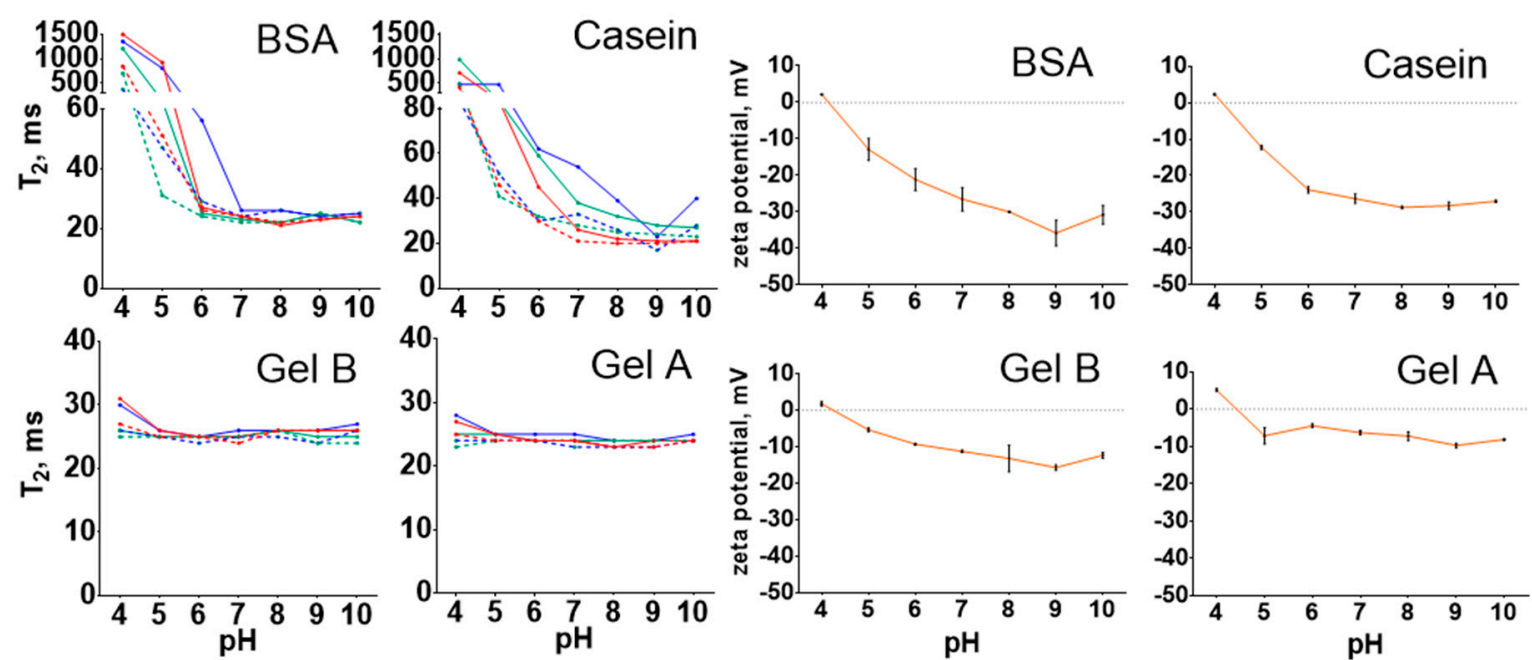

Figure 8. The T2 relaxation times of Fe@C- $\mathrm{NH}_{2} /$ Protein/G diluted in buffers with different $\mathrm{pH}$ and ionic strength values and the zeta potentials of Fe@C-NH$/$ Protein/G. "BSA”, “Casein”, "Gel B", and "Gel A" indicate coating protein. T2 in $0.15 \mathrm{M}$ (red line), $0.5 \mathrm{M}$ (green line), and $2 \mathrm{M}$ (blue line) buffers at 0 (dashed line) and $24 \mathrm{~h}$ (solid line), $n=3$, mean $\pm \mathrm{SD}$.

We can conclude that our results are consistent with those of previous studies; however, a direct comparison is complicated because of the different functionalization strategies. In our study, gelatin-coated magnetic nanoclusters were almost insensitive to $\mathrm{pH}$ variations in the range from 4 to 10 , and BSA- and casein-coated nanoclusters aggregated at $\mathrm{pH}$ values near the isoelectric points of these proteins. Notably, such behaviors correspond with the zeta potential variations: the zeta potentials of Fe@C-NH $/$ BSA/G and Fe@C- $\mathrm{NH}_{2} /$ Casein/G are between 0 and $-20 \mathrm{mV}$ at pH 4 and 5 (Figure 8). Surprisingly, there is no such distinct relationship between the zeta potential of gelatin-coated Fe@C- $-\mathrm{NH}_{2}$ and its aggregation state. Moreover, despite the zeta potentials of both Fe@C- $\mathrm{NH}_{2} / \mathrm{Gelatin}$ $\mathrm{A} / \mathrm{G}$ and Fe@C-NH$/$ /Gelatin B/G being very low in comparison with the widely accepted $\pm 30 \mathrm{mV}$ stability threshold, they withstand aggregation, even at high ionic strengths, indicating the more significant role of hydration forces [68] and steric rather than the electrostatic repulsion between gelatin-coated nanoparticles [69]. Casein-coated nanoclusters are more sensitive to the increase in salt concentration. Therefore, we suppose that mainly the surface charge provides stability to these nanoclusters.

\subsection{Storage Stability}

The practical implementation of nanoparticle-based diagnostic reagents requires them to be stable for extended periods [70]. We monitored the size and polydispersity of Fe@C- $\mathrm{NH}_{2} / \mathrm{Protein} / \mathrm{G}$, which 
was stored at +4 and $+37^{\circ} \mathrm{C}$ for four weeks. A temperature range from +2 to $+8{ }^{\circ} \mathrm{C}$ is widely used for the storage of bioreagents, including test kits and diagnostic reagents (e.g., enzyme conjugates). The exposure of components of test kits to elevated temperatures is a rapid and efficient way to assess their long-term stability. According to [71], seven days at $+37^{\circ} \mathrm{C}$ is equivalent to one year at $+4{ }^{\circ} \mathrm{C}$. Apparently, this approximation applies mainly to proteinaceous reagents, which are liable to thermal denaturation. However, nanoparticles aimed for use in in vivo applications are also tested under accelerated conditions [72].

The hydrodynamic diameter and polydispersity of protein-coated nanoclusters did not alter after one month of the storage. The most notable change was observed for Fe@C-NH$/ \mathrm{N}_{2} / \mathrm{Csein} / \mathrm{G}$ stored at $+4{ }^{\circ} \mathrm{C}$, in which the size was increased from 128 to $142 \mathrm{~nm}$ (Figure 9). At the same time, elevated temperatures did not affect the size of this conjugate. Therefore, the growth of nanoclusters at $+4{ }^{\circ} \mathrm{C}$ was rather due to the variability in the measurements. To reinforce these results, we assessed the diameter and polydispersity alterations of the nanoclusters obtained during the course of the size-tuning experiments, which were stored for four months (Figure S15). Generally, there were no systematic changes in the hydrodynamic diameters. A time-dependent size alteration in some samples (denoted with arrows in Figure S15) can be attributed mainly to the variability of the DLS method because not only increases but also decreases in the mean diameter after storage were observed.

(a)
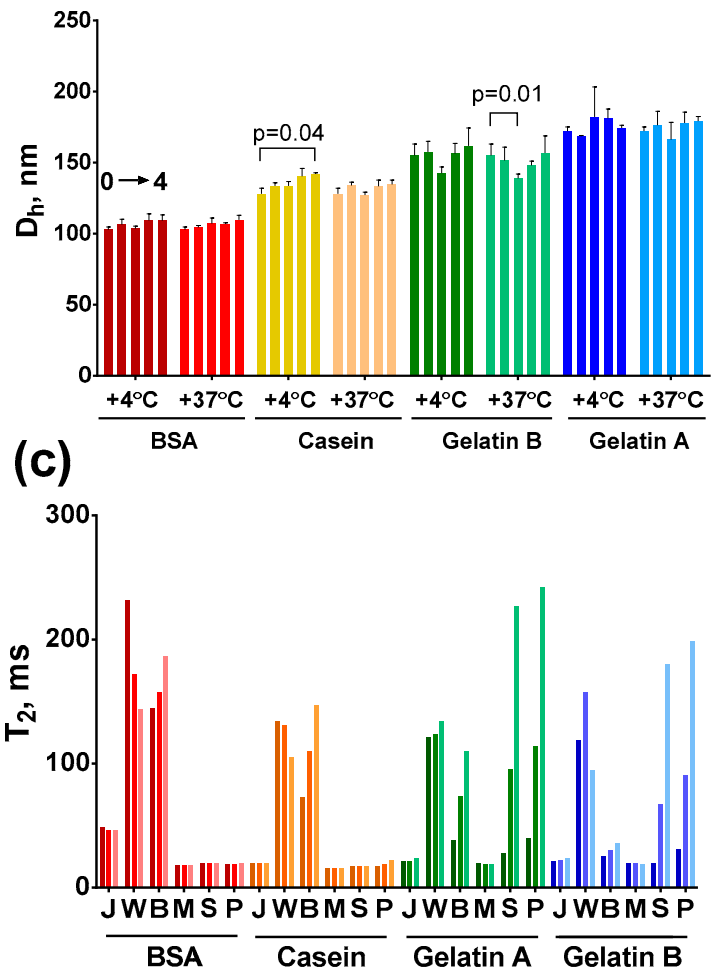

(b)
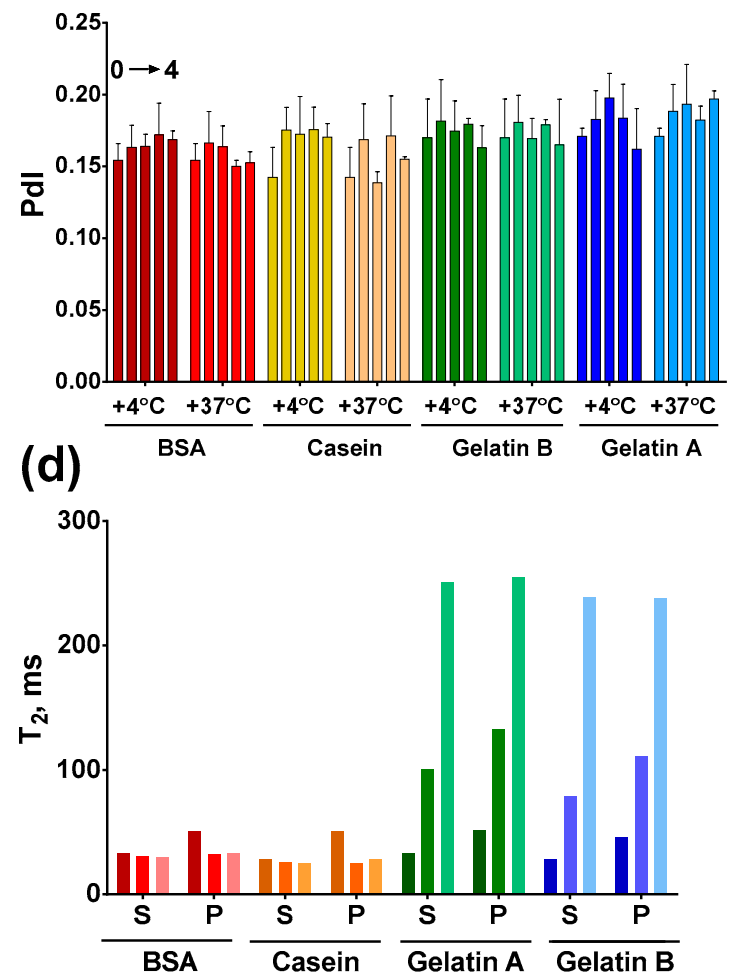

Figure 9. Storage stability of Fe@C-NH$/$ Protein/G and stability of Fe@C-NH $/$ Protein/G and Fe@C-NH $\mathrm{N}_{2}$ Protein/Str in complex media. Upper row: changes in hydrodynamic diameter (a) and polydispersity index (b) during four weeks of storage at different temperatures; the five bars represent the size or PdI at week 0, 1, 2, 3, and 4 (from left to right), statistics: two-way ANOVA with Dunnet's post-hoc test, $n=3$, mean \pm SD; lower row: the T2 of Fe@C-NH $2 /$ Protein/G (c) and Fe@C-NH $2 /$ Protein/Str (d) diluted in juice $(\mathrm{J})$, wine $(\mathrm{W})$, beer $(\mathrm{B})$, milk $(\mathrm{M})$, blood serum $(\mathrm{S})$, and plasma $(\mathrm{P})$; the three bars represent $\mathrm{T} 2$ at 0,1 , and $5 \mathrm{~h}$ (from left to right). 


\subsection{Stability of Nanoclusters in Complex Media}

Magnetic nanoparticles are widely used in the homogeneous assays of pathogens, toxins, heavy metals, and other analytes in food, physiological, and environmental samples. In the course of these assays, the nanoparticles encounter a complex mixture of proteins, carbohydrates, lipids, and their complexes, which can induce nanoparticle aggregation and the subsequent loss of functions. The nonspecific aggregation of nanoparticles is undesirable for aggregation-based assays (e.g., T2 relaxometry) because it leads to false-positive results. Moreover, the aggregation of nanoparticles can reduce the efficiency of the magnetic enrichment [73]. We studied the stability of protein-coated nanoclusters in blood serum/plasma, orange juice, milk, red wine, and beer by T2 relaxometry. Plasma and serum are among the most significant specimens in clinical diagnostics; milk, juice, beer, and wine are popular foods that are usually tested for the presence of pathogens and their toxins before becoming available to consumers. The tested media do not contain any magnetic material, and hence, do not affect the results of the T2 relaxometry, which depends only on the aggregation of magnetic nanoparticles diluted in these media [74]. Most of the nanoparticle-based assays require only minutesto hours-long incubations of nanoprobes in the samples under study. Therefore, we assessed the T2 change of diluted nanoclusters after 1 and $5 \mathrm{~h}$ of incubation.

There was no significant change in T2 after the incubation of casein- and BSA-coated nanoclusters in juice, milk, and blood serum/plasma. An increase in T2 was observed for all four types of nanoclusters diluted in beer. However, for Fe@C- $\mathrm{NH}_{2} / \mathrm{BSA} / \mathrm{G}$ and Fe@C-NH$/ 2$ Casein/G, a sharp increase in T2 was observed for the gelatin-coated nanoclusters after dilution in serum and plasma. Moreover, aggregates of gelatin-encapsulated nanoclusters in blood samples were visible by the naked eye. The aggregation of gelatin-coated nanoclusters was not associated with the interaction between protein $\mathrm{G}$ and the IgG from the plasma/serum because the experiment with Fe@C-NH $2 /$ Protein/Str produced the same result (Figure 9). All tested conjugates were aggregated in red wine. The complex relationship between the size and surface structure of nanoparticles and their relaxivity is well known [13]. Thus, we cannot fully explain the alteration of $\mathrm{T} 2$ in each case. Nevertheless, the aggregation of nanoclusters and adsorption of the media's components on their surface definitely have a significant impact. According to the obtained results, we can conclude that gelatin-coated nanoclusters are inappropriate for the determination of analytes both in undiluted serum and plasma. All four conjugates can be added to whole milk and juice.

\subsection{Protein Corona}

The blood serum composition represents a variety of pathological and physiological processes that makes serum one of the most informative and important clinical specimens. Nonspecific interactions of nanoparticles with serum components are inevitable when their mixing takes place during the assay procedure. Matrix interference is a significant issue in magnetic nanoparticle-based biosensing, causing a dramatic decrease in specificity [75]. According to recent reports, protein shells can provide antifouling properties by decreasing the amount of nonspecific binding of cells and medium components, first of all, serum proteins $[65,76,77]$. At the same time, the coating of nanoparticles with biocompatible natural polymers can increase the nonspecific protein binding [78]. Herein, we assessed the adsorption of serum proteins on the surface of Fe@C- $\mathrm{NH}_{2} /$ Protein/Str by SDS-PAGE and Bradford assays.

Different protein coronas are formed after the incubation of nanoclusters in serum and plasma (Figure 10 and Figure S16). The overall amount of adsorbed protein from blood serum was the same for both coated nanoclusters and parent uncoated nanoparticles $\left(\mathrm{Fe} @ \mathrm{C}-\mathrm{NH}_{2}\right)$ except for Fe@C-NH $2 / G e l a t i n$ A/Str, which was bound with twice as much protein. However, we should note that direct comparisons of protein binding capacity are not completely correct because protein quantification by Coomassie staining depends on the amino acid composition of the protein under study. We find explaining the increased serum protein binding by gelatin-A-coated nanoclusters to be quite challenging, especially in the light of the fact that gelatins $A$ and $B$ have the same protein binding pattern and that the protein bands in stained gels have the same intensity. Moreover, according to SDS-PAGE, a significantly higher 
adsorption of plasma proteins by Fe@C- $\mathrm{NH}_{2} /$ Gelatin B/Str was revealed (Figure 10). The protein coating did not reduce the nonspecific binding of serum proteins but rather led to a change in the composition of the protein corona. This fact corresponds with the results of Mirshafiee et al., who demonstrated that proteins could promote the adsorption of certain groups of serum proteins and reduce the adsorption of others in comparison with uncoated nanoparticles [79]. Additionally, smaller nanoparticles bind less protein from serum/plasma both per nanoparticle [80] and per unit area [81]. Uncoated Fe@C- $\mathrm{NH}_{2}$ nanoparticles have the lowest hydrodynamic diameter; however, they rapidly aggregate upon mixing with serum, and an accurate determination of their diameter is complicated. Gelatin A-coated nanoclusters are the largest one, but their size is only $30 \mathrm{~nm}$ larger than that of Fe@C-NH ${ }_{2} /$ Gelatin B/Str (186 nm vs. 154 nm). At the same time, Fe@C-NH $/$ BSA/Str $(111 \mathrm{~nm})$ and Fe@C-NH $2 /$ Casein/Str (119 nm) are approximately 30-40 nm smaller than Fe@C-NH $\mathrm{NH}_{2} /$ Gelatin B/Str, but they all adsorb the same amount of protein.

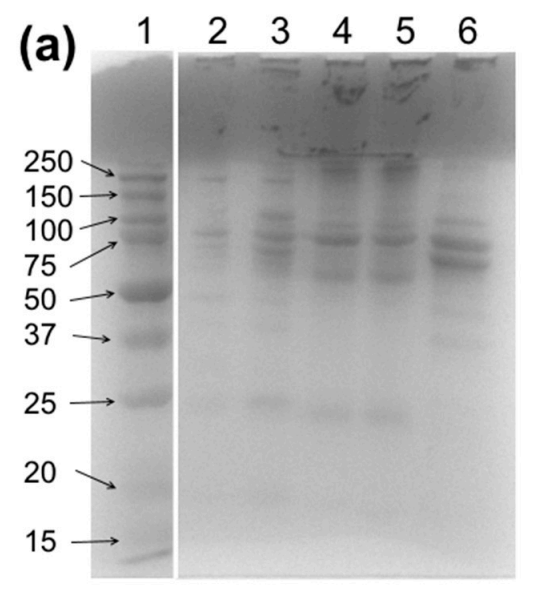

(b)

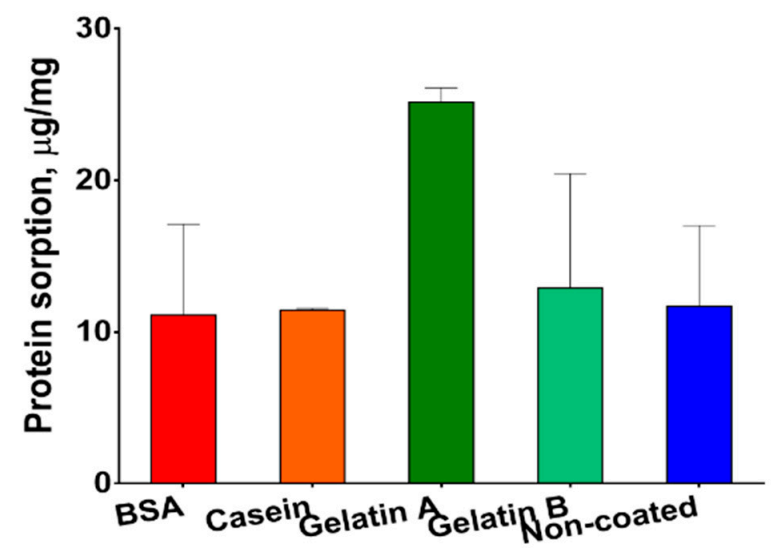

(c)

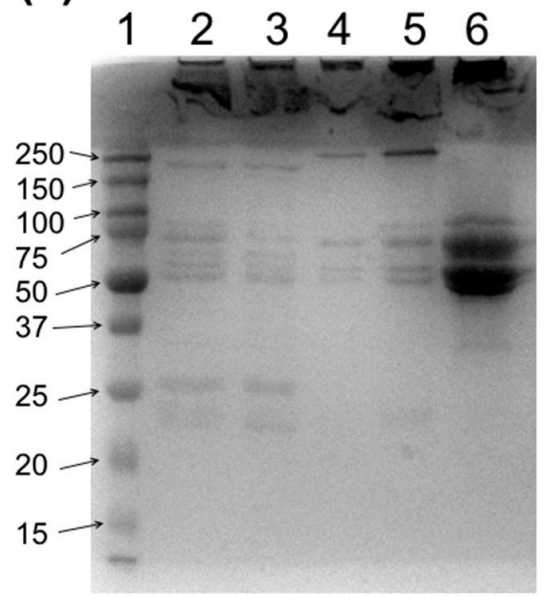

(d)

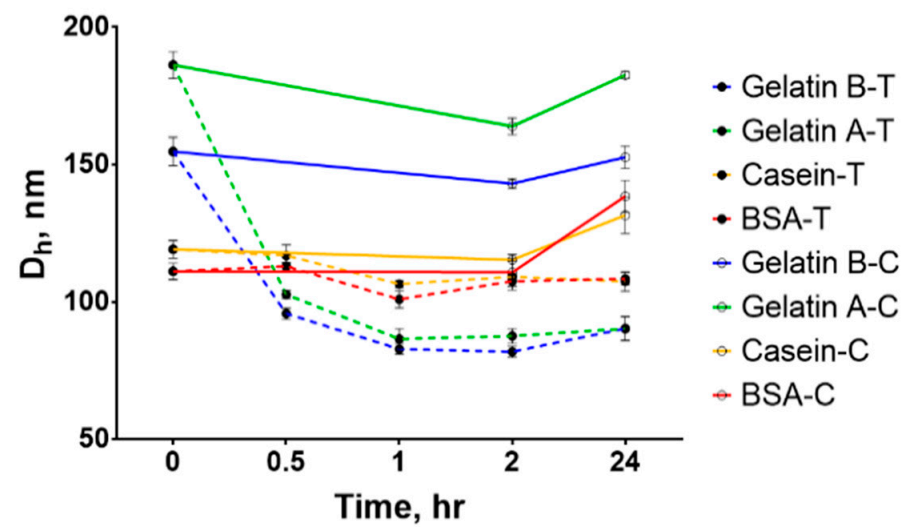

Figure 10. Protein corona and stability of nanoclusters to proteolysis. Protein coronas of Fe@C-NH $/$ BSA/Str (lane 2), Fe@C-NH $2 /$ Casein/Str (lane 3), Fe@C-NH $2 /$ Gelatin A/Str (lane 4), Fe@C-NH $2 /$ Gelatin B/Str (lane 5), and Fe@C-NH $\mathrm{NH}_{2}$ (lane 6) in blood serum (a) and plasma (c), with lane 1-protein markers (kDa). (b) The sorption of serum proteins on Fe@C-NH $\mathrm{NH}_{2} /$ Protein/Str and Fe@C-NH 2 . (d) The size of Fe@C-NH$/$ Protein/Str after incubation in the trypsin solution (dashed line, filled circles) or PBS (solid line, open circles). Coating: BSA (red), casein (yellow), gelatin A (green) and B (blue), $n=3$, mean \pm SD.

\subsection{The Resistance of Nanoclusters to Proteolysis}

Proteolytic cleavage by proteases from the environment reduces the shelf-life of proteins and their conjugates [82]. To assess the impact of protease digestion on the structural integrity of protein-coated 
magnetic nanoclusters, the latter were mixed with a trypsin solution, and the Fe@C-NH$/ \mathrm{H}_{2} / \mathrm{Protein} / \mathrm{Str}$ size was monitored within $24 \mathrm{~h}$. We used trypsin at high concentration $(100 \mu \mathrm{g} / \mathrm{mL})$, similar to that of the intestinal secretion of a human adult (approx. 100-500 $\mu \mathrm{g} / \mathrm{mL}$ ) [83], to provide an accelerated study.

An almost two-fold drop in the mean diameter of gelatin-coated nanoclusters was observed after $1 \mathrm{~h}$ of incubation (Figure 10) without further changes. Conversely, only a slight decrease in BSAand casein-coated nanocluster diameters occurred. After $24 \mathrm{~h}$ of agitation at $+37^{\circ} \mathrm{C}$, the size of the nanoclusters increased in the control samples (without trypsin) but not in the test samples. In the previous sections, we noted that all conjugates were stable to heating; however, in this experiment, highly diluted $(10 \mu \mathrm{g} / \mathrm{mL})$ suspensions were used without the addition of stabilizers including BSA, glycerol, and glycine. These results demonstrate that stabilizers are essential for the preservation of conjugates' properties. Interestingly, after the trypsin treatment, the Z-average diameter of the gelatin-coated nanoclusters was approximately 60-80 nm, which is equal to that of the parent Fe@C- $\mathrm{NH}_{2}$. A possible explanation for the different stabilities of coatings to proteolytic digestion is given below.

According to [84], the trypsin degradation rate of albumin nanoparticles covalently linked with glutaraldehyde is inversely proportional to the cross-linking degree, and only $9 \%$ of nanoparticles degraded within $24 \mathrm{~h}$. Similar results were obtained for the ionically cross-linked casein nanoparticles [85]. In our work, we used a great molar excess of glutaraldehyde capable of involving all available primary amine groups in cross-linking reactions. Gelatins A and B contain the lowest amount (3.29\% and 4.01\%) of lysine [86] in comparison with that of casein $(8.10 \%)$ and BSA $(15.30 \%)$ [87,88]; therefore, fewer cross-links are formed between the primary amines of gelatin molecules [89]. Other factors such as conformation differences among the adsorbed proteins and their availability to proteolytic cleavage can also contribute to higher/lower resistance of nanoparticles to trypsinolysis. For example, Cao et al. demonstrated that adsorption on titanium dioxide nanoparticles can protect casein against gastric and intestinal digestion [90], and gold nanoparticles coated with proteins were stable for several days in PBS containing a proteolytic enzyme [91].

\section{Conclusions}

Protein coatings endow nanoparticles with several favorable properties, enhancing their performance in various biomedical applications. In the present study, we synthesized nanoclusters of magnetic iron-carbon nanoparticles coated with four proteins (BSA, casein from bovine milk, and gelatins A and B), examined their physical-chemical properties from the perspective of applications for in vitro diagnostics and used nanoclusters conjugated with Streptococcal protein G as labels in an NMR immunoassay of IgG against the tetanus toxoid. The developed immunoassay allows for the determination of protection against tetanus in patients vaccinated with the diphtheria-tetanus-pertussis vaccine.

All types of protein coatings provide the nanoclusters with an excellent long-term storage stability. The gelatin layer prevents nanoclusters from aggregating over a wide range of $\mathrm{pH}$ : from 4 to 10 , whereas casein- and BSA-coated nanoclusters are stable at $\mathrm{pH}$ 6-10. The protein-coated nanoclusters withstand salt concentrations up to $2 \mathrm{M}$ without a significant change in size. We demonstrated that protein-coated magnetic nanoparticles maintain their size in complex media (juice, milk, serum, and plasma) and at elevated temperatures, facilitating their applications in homogeneous assays of biomarkers and foodborne pathogens, as well as their analyses based on the amplification of nucleic acids. The type of protein coating and size of nanocluster do not significantly affect the $r 2$ relaxivity of nanoclusters or their performance in NMR-assays. Generally, the transverse relaxivity of protein-coated nanoclusters was between 200 and $3501 / \mathrm{mM}^{-1} \times \mathrm{s}^{-1}$.

We suppose that the developed protein-coated nanoclusters can be applied for not only in vitro but also in vivo diagnostics (e.g., as a T2 contrast in MRI) due to their good stability in physiological media and high relaxivity (in comparison with clinically approved nanolabels) [23]. The proteins are biocompatible and biodegradable; moreover, the protein layer can be loaded with therapeutics or various labels, providing multimodal imaging. 
Supplementary Materials: The following are available online at http://www.mdpi.com/2079-4991/9/9/1345/s1, Experimental section (description of preparation of the conjugates with different sizes), Figure S1. Casein solution before (right) and after (left) removal of micelles; Figure S2. Zeta potential of Fe@C-NH 2 ; Figure S3. Influence of $\mathrm{pH}$, ionic strength, and protein-to-nanoparticle mass ratio on the size (hydrodynamic diameter) and polydispersity index of BSA-coated Fe@C-NH${ }_{2}$; Figure S4. Influence of $\mathrm{pH}$, ionic strength, and protein-to-nanoparticle mass ratio on the size (hydrodynamic diameter) and polydispersity index of casein-coated Fe@C-NH $\mathrm{H}_{2}$; Figure S5. Influence of $\mathrm{pH}$, ionic strength, and protein-to-nanoparticle mass ratio on the size (hydrodynamic diameter) and polydispersity index of gelatin B-coated Fe@C- $\mathrm{NH}_{2} ;$ Figure S6. Influence of $\mathrm{pH}$ and protein-to-nanoparticle mass ratio on the size (hydrodynamic diameter) and polydispersity index of Gelatin A-coated Fe@C-NH ${ }_{2} ;$ Figure S7. Influence of sonication duration on size and polydispersity of Gelatin B-stabilized Fe@C-NH $\mathrm{NH}_{2}(\mathrm{pH}, \mathrm{I}=0.5)$;

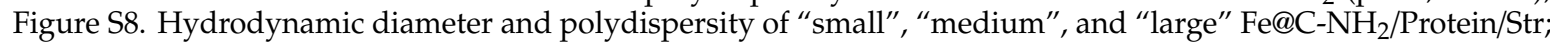
Figure S9. Zeta potential of "small", "medium", and "large" Fe@C-NH $2 /$ Protein/Str; Figure S10. Migration of $\mathrm{Fe} @ \mathrm{C}-\mathrm{NH}_{2} /$ protein/Str and Fe@C-NH$/$ protein/G in $0.5 \%$ agarose gel (Tris- $\mathrm{HCl} \mathrm{pH} 8,75 \mathrm{~V}$ ); Figure S11. Principle of NMR-assay of Bi-BSA on nitrocellulose membrane (top). Sample holder with test strip (bottom); Figure S12. Functional activity of "small", "medium", and "large" Fe@C-NH2/Protein/Str in solid phase NMR-assay; Figure S13. Day-to-day reproducibility of anti-tetanus toxoid NMR-assay; Figure S14. Comparison of ELISA and NMR-assay of IgG against tetanus toxoid; Figure S15. Storage stability of Fe@C-NH $/$ Protein/Str nanoparticles, obtained in the course of size tuning experiments; Figure S16. Protein corona of Fe@C-NH $/$ Protein/Str after incubation in blood serum and plasma; Table S1. Properties of conjugates used in this study.

Author Contributions: Investigation, P.K., I.B., M.K., M.B., V.T., A.N., I.B., S.Z., A.Y. and M.R.; Visualization, P.K.; Writing-original draft, P.K., S.Z., A.Y. and M.R. All authors have given approval to the final version of the manuscript.

Funding: This work was supported by the Russian Science Foundation (grant No. 17-15-01116).

Acknowledgments: We thank Olga Pistsova (PSU) and Grigory Glebov (PSU) for their help in AFM characterizations, Ekaterina Stepanova (PSU) and Ricardo Milos (PSU) for buffer titration experiments, Artem Minin (IMP UB RAS) for his of TEM characterizations, Dmitry Sharavin (IEGM UB RAS) for his help of UV-VIS spectroscopy.

Conflicts of Interest: The authors declare no conflict of interest.

\section{References}

1. Cardoso, V.F.; Francesko, A.; Ribeiro, C.; Bañobre-López, M.; Martins, P.; Lanceros-Mendez, S. Advances in Magnetic Nanoparticles for Biomedical Applications. Adv. Healthc. Mater. 2018, 7. [CrossRef] [PubMed]

2. Farka, Z.; Juř́k, T.; Kovář, D.; Trnková, L.; Skládal, P. Nanoparticle-Based Immunochemical Biosensors and Assays: Recent Advances and Challenges. Chem. Rev. 2017, 117, 9973-10042. [CrossRef] [PubMed]

3. Huang, Z.; Hu, S.; Xiong, Y.; Wei, H.; Xu, H.; Duan, H.; Lai, W. Application and development of superparamagnetic nanoparticles in sample pretreatment and immunochromatographic assay. Trends Anal. Chem. 2019, 114, 151-170. [CrossRef]

4. Rocha-Santos, T.A.P. Sensors and biosensors based on magnetic nanoparticles. Trends Anal. Chem. 2014, 62, 28-36. [CrossRef]

5. Syedmoradi, L.; Daneshpour, M.; Alvandipour, M.; Gomez, F.A.; Hajghassem, H.; Omidfar, K. Point of care testing: The impact of nanotechnology. Biosens. Bioelectron. 2017, 87, 373-387. [CrossRef] [PubMed]

6. Li, J.; Wang, S.; Shi, X.; Shen, M. Aqueous-phase synthesis of iron oxide nanoparticles and composites for cancer diagnosis and therapy. Adv. Colloid Interface Sci. 2017, 249, 374-385. [CrossRef] [PubMed]

7. Zhang, Y.; Yang, H.; Zhou, Z.; Huang, K.; Yang, S.; Han, G. Recent Advances on Magnetic Relaxation Switching Assay-Based Nanosensors. Bioconj. Chem. 2017, 28, 869-879. [CrossRef]

8. Shao, H.; Min, C.; Issadore, D.; Liong, M.; Yoon, T.-J.; Weissleder, R.; Lee, H. Magnetic nanoparticles and micronmr for diagnostic applications. Theranostics 2012, 2, 55-65. [CrossRef]

9. Haun, J.B.; Yoon, T.-J.; Lee, H.; Weissleder, R. Magnetic nanoparticle biosensors. Wiley Interdiscip. Rev. Nanomed. Nanobiotechnol. 2010, 2, 291-304. [CrossRef]

10. Alcantara, D.; Lopez, S.; García-Martin, M.L.; Pozo, D. Iron oxide nanoparticles as magnetic relaxation switching (MRSw) sensors: Current applications in nanomedicine. Nanomed. Nanotechnol. Biol. Med. 2016, 12, 1253-1262. [CrossRef]

11. Luo, Z.-X.; Fox, L.; Cummings, M.; Lowery, T.J.; Daviso, E. New frontiers in in vitro medical diagnostics by low field T2 magnetic resonance relaxometry. Trends Anal. Chem. 2016, 83, 94-102. [CrossRef]

12. Fung, F.; Wang, H.-S.; Menon, S. Food safety in the 21st century. Biomed. J. 2018, 41, 88-95. [CrossRef] [PubMed] 
13. Zhou, Z.; Yang, L.; Gao, J.; Chen, X. Structure-Relaxivity Relationships of Magnetic Nanoparticles for Magnetic Resonance Imaging. Adv. Mater. 2019, 31. [CrossRef] [PubMed]

14. Xianyu, Y.; Wang, Q.; Chen, Y. Magnetic particles-enabled biosensors for point-of-care testing. Trends Anal. Chem. 2018, 106, 213-224. [CrossRef]

15. Biehl, P.; von der Lühe, M.; Dutz, S.; Schacher, F.H. Synthesis, characterization, and applications of magnetic nanoparticles featuring polyzwitterionic coatings. Polymers 2018, 10, 91. [CrossRef] [PubMed]

16. Elzoghby, A.O.; Hemasa, A.L.; Freag, M.S. Hybrid protein-inorganic nanoparticles: From tumor-targeted drug delivery to cancer imaging. J. Control. Release 2016, 243, 303-322. [CrossRef] [PubMed]

17. An, F.-F.; Zhang, X.-H. Strategies for preparing albumin-based nanoparticles for multifunctional bioimaging and drug delivery. Theranostics 2017, 7, 3667-3689. [CrossRef] [PubMed]

18. Guerrini, L.; Alvarez-Puebla, R.A.; Pazos-Perez, N. Surface modifications of nanoparticles for stability in biological fluids. Materials 2018, 11, 1154. [CrossRef]

19. Schubert, J.; Chanana, M. Coating matters: Review on colloidal stability of nanoparticles with biocompatible coatings in biological media, living cells and organisms. Curr. Med. Chem. 2018, 25, 4553-4586. [CrossRef]

20. Gou, Y.; Miao, D.; Zhou, M.; Wang, L.; Zhou, H.; Su, G. Bio-inspired protein-based nanoformulations for cancer theranostics. Front. Pharmacol. 2018, 9, 421. [CrossRef]

21. Gulati, N.M.; Stewart, P.L.; Steinmetz, N.F. Bioinspired Shielding Strategies for Nanoparticle Drug Delivery Applications. Mol. Pharm. 2018, 15, 2900-2909. [CrossRef] [PubMed]

22. Spicer, C.D.; Jumeaux, C.; Gupta, B.; Stevens, M.M. Peptide and protein nanoparticle conjugates: Versatile platforms for biomedical applications. Chem. Soc. Rev. 2018, 47, 3574-3620. [CrossRef] [PubMed]

23. Zhang, W.; Liu, L.; Chen, H.; Hu, K.; Delahunty, I.; Gao, S.; Xie, J. Surface impact on nanoparticle-based magnetic resonance imaging contrast agents. Theranostics 2018, 8, 2521-2548. [CrossRef] [PubMed]

24. Foox, M.; Zilberman, M. Drug delivery from gelatin-based systems. Expert Opin. Drug Deliv. 2015, 12, 1547-1563. [CrossRef] [PubMed]

25. Elzoghby, A.O.; Abo El-Fotoh, W.S.; Elgindy, N.A. Casein-based formulations as promising controlled release drug delivery systems. J. Control. Release 2011, 153, 206-216. [CrossRef] [PubMed]

26. Wu, T.; Tang, M. Review of the effects of manufactured nanoparticles on mammalian target organs. J. Appl. Toxicol. 2018, 38, 25-40. [CrossRef] [PubMed]

27. Santoro, M.; Tatara, A.M.; Mikos, A.G. Gelatin carriers for drug and cell delivery in tissue engineering. J. Control. Release 2014, 190, 210-218. [CrossRef] [PubMed]

28. Mikhalev, K.N.; Germov, A.Y.; Uimin, M.A.; Yermakov, A.E.; Konev, A.S.; Novikov, S.I.; Gaviko, V.S.; Ponosov, Y.S. Magnetic state and phase composition of carbon-encapsulated Co@C nanoparticles according to 59Co, 13C NMR data and Raman spectroscopy. Mater. Res. Express 2018, 5, 055033. [CrossRef]

29. Pitkowski, A.; Durand, D.; Nicolai, T. Structure and dynamical mechanical properties of suspensions of sodium caseinate. J. Colloid Interface Sci. 2008, 326, 96-102. [CrossRef] [PubMed]

30. Saha, D.; Acharya, D.; Dhar, T.K. Method for Homogeneous Spotting of Antibodies on Membranes: Application to the Sensitive Detection of Ochratoxin A. Anal. Bioanal. Chem. 2006, 385, 847-854. [CrossRef] [PubMed]

31. Hanauer, M.; Pierrat, S.; Zins, I.; Lotz, A.; Sönnichsen, C. Separation of nanoparticles by gel electrophoresis according to size and shape. Nano Lett. 2007, 7, 2881-2885. [CrossRef] [PubMed]

32. Riesz, P.; Kondo, T. Free radical formation induced by ultrasound and its biological implications. Free Radic. Biol. Med. 1992, 13, 247-270. [CrossRef]

33. Khramtsov, P.; Kropaneva, M.; Byzov, I.; Minin, A.; Mysik, A.; Timganova, V.; Bochkova, M.; Uimin, M.; Zamorina, S.; Yermakov, A.; et al. Conjugation of carbon coated-iron nanoparticles with biomolecules for NMR-based assay. Colloids Surf. B 2019, 176, 256-264. [CrossRef]

34. Leskinen, T.; Witos, J.; Valle-Delgado, J.J.; Lintinen, K.; Kostiainen, M.; Wiedmer, S.K.; Österberg, M.; Mattinen, M.L. Adsorption of Proteins on Colloidal Lignin Particles for Advanced Biomaterials. Biomacromolecules 2017, 18, 2767-2776. [CrossRef] [PubMed]

35. Sangeetha, J.; Philip, J. The interaction, stability and response to an external stimulus of iron oxide nanoparticle-casein nanocomplexes. Colloids Surf. A 2012, 406, 52-60. [CrossRef]

36. Wang, Y.; Xu, H.; Wei, M.; Gu, H.; Xu, Q.; Zhu, W. Study of superparamagnetic nanoparticles as labels in the quantitative lateral flow immunoassay. Mater. Sci. Eng. C 2009, 29, 714-718. [CrossRef] 
37. Koh, I.; Hong, R.; Weissleder, R.; Josephson, L. Sensitive NMR sensors detect antibodies to influenza. Angew. Chem. Int. Ed. 2008, 47, 4119-4121. [CrossRef] [PubMed]

38. Cowger, T.A.; Tang, W.; Zhen, Z.; Hu, K.; Rink, D.E.; Todd, T.J.; Wang, G.D.; Zhang, W.; Chen, H.; Xie, J. Casein-coated Fe5C2 nanoparticles with superior $\mathrm{r} 2$ relaxivity for liver-specific magnetic resonance imaging. Theranostics 2015, 5, 1225-1232. [CrossRef]

39. Shamsutdinova, N.; Zairov, R.; Nizameev, I.; Gubaidullin, A.; Mukhametshina, A.; Podyachev, S.; Ismayev, I.; Kadirov, M.; Voloshina, A.; Mukhametzyanov, T.; et al. Tuning magnetic relaxation properties of "hard cores" in core-shell colloids by modification of "soft shell". Colloids Surf. B 2018, 162, 52-59. [CrossRef]

40. Park, J.C.; Lee, G.T.; Kim, H.-K.; Sung, B.; Lee, Y.; Kim, M.; Chang, Y.; Seo, J.H. Surface Design of Eu-Doped Iron Oxide Nanoparticles for Tuning the Magnetic Relaxivity. ACS Appl. Mater. Interfaces 2018, 10, 25080-25089. [CrossRef]

41. Roca, A.G.; Veintemillas-Verdaguer, S.; Port, M.; Robic, C.; Serna, C.J.; Morales, M.P. Effect of nanoparticle and aggregate size on the relaxometric properties of MR contrast agents based on high quality magnetite nanoparticles. J. Phys. Chem. B 2009, 113, 7033-7039. [CrossRef] [PubMed]

42. WHO. Tetanus vaccines: WHO position paper-February 2017. Relev. Epidemiol. Hebd. 2017, 92, 53-76.

43. Kristiansen, M.; Aggerbeck, H.; Heron, I. Improved ELISA for determination of anti-diphtheria and/or anti-tetanus antitoxin antibodies in sera. APMIS 1997, 105, 843-853. [CrossRef] [PubMed]

44. Van Gageldonk, P.G.M.; van Schaijk, F.G.; van der Klis, F.R.; Berbers, G.A.M. Development and validation of a multiplex immunoassay for the simultaneous determination of serum antibodies to Bordetella pertussis, diphtheria and tetanus. J. Immunol. Methods 2008, 335, 79-89. [CrossRef] [PubMed]

45. Liu, J.; Wang, J.; Li, Z.; Meng, H.; Zhang, L.; Wang, H.; Li, J.; Qu, L. A lateral flow assay for the determination of human tetanus antibody in whole blood by using gold nanoparticle labeled tetanus antigen. Microchim. Acta 2018, 185, 110. [CrossRef] [PubMed]

46. Raeisi, S.; Molaeirad, A.; Sadri, M.; Nejad, H.R. Detection of Anti-tetanus Toxoid Monoclonal Antibody by Using Modified Polycarbonate Surface. Plasmonics 2018, 13, 1555-1567. [CrossRef]

47. Jain, S.; Chattopadhyay, S.; Jackeray, R.; Zainul Abid, C.K.V.; Kumar, M.; Singh, H. Detection of anti-tetanus toxoid antibody on modified polyacrylonitrile fibers. Talanta 2010, 82, 1876-1883. [CrossRef]

48. Golberg, A.; Yarmush, M.L.; Konry, T. Picoliter droplet microfluidic immunosorbent platform for point-of-care diagnostics of tetanus. Microchim. Acta 2013, 180, 855-860. [CrossRef]

49. Tian, B.; Liao, X.; Svedlindh, P.; Strömberg, M.; Wetterskog, E. Ferromagnetic Resonance Biosensor for Homogeneous and Volumetric Detection of DNA. ACS Sens. 2018, 3, 1093-1101. [CrossRef]

50. Jansaento, W.; Jangpatarapongsa, K.; Polpanich, D.; Wonglumsom, W. Detection of Campylobacter DNA using magnetic nanoparticles coupled with PCR and a colorimetric end-point system. Food Sci. Biotechnol. 2016, 25, 193-198. [CrossRef]

51. Bigi, A.; Cojazzi, G.; Panzavolta, S.; Rubini, K.; Roveri, N. Mechanical and thermal properties of gelatin films at different degrees of glutaraldehyde crosslinking. Biomaterials 2001, 22, 763-768. [CrossRef]

52. Capomaccio, R.; Osório, I.; Ojea-Jiménez, I.; Ceccone, G.; Colpo, P.; Gilliland, D.; Hussain, R.; Siligardi, G.; Rossi, F.; Ricard-Blum, S.; et al. Gold nanoparticles increases UV and thermal stability of human serum albumin. Biointerphases 2016, 11, 04B310. [CrossRef] [PubMed]

53. Canpean, V.; Gabudean, A.M.; Astilean, S. Enhanced thermal stability of gelatin coated gold nanorods in water solution. Colloids Surf. A 2013, 433, 9-13. [CrossRef]

54. Moriyama, Y.; Watanabe, E.; Kobayashi, K.; Harano, H.; Lnui, E.; Takeda, K. Secondary structural change of bovine serum albumin in thermal denaturation up to $130{ }^{\circ} \mathrm{C}$ and protective effect of sodium dodecyl sulfate on the change. J. Phys. Chem. B 2008, 112, 16585-16589. [CrossRef] [PubMed]

55. Van Der Lee, R.; Buljan, M.; Lang, B.; Weatheritt, R.J.; Daughdrill, G.W.; Dunker, A.K.; Fuxreiter, M.; Gough, J.; Gsponer, J.; Jones, D.T.; et al. Classification of intrinsically disordered regions and proteins. Chem. Rev. 2014, 114, 6589-6631. [CrossRef] [PubMed]

56. Huang, Y.-Y.; Kuo, W.-T.; Huang, H.-Y.; Chou, M.-J.; Wu, M.-C. Surface modification of gelatin nanoparticles with polyethylenimine as gene vector. J. Nanomater. 2011, 2011. [CrossRef]

57. Gaihre, B.; Aryal, S.; Khil, M.S.; Kim, H.Y. Encapsulation of $\mathrm{Fe}_{3} \mathrm{O}_{4}$ in gelatin nanoparticles: Effect of different parameters on size and stability of the colloidal dispersion. J. Microencapsul. 2008, 25, 21-30. [CrossRef] [PubMed] 
58. Sivera, M.; Kvitek, L.; Soukupova, J.; Panacek, A.; Prucek, R.; Vecerova, R.; Zboril, R. Silver nanoparticles modified by gelatin with extraordinary $\mathrm{pH}$ stability and long-term antibacterial activity. PLOS ONE 2014, 9, e103675. [CrossRef]

59. Gaihre, B.; Parajuli, D.C.; Seo, H.C.; Khil, M.S.; Kim, H.Y. Effect of different parameters on gelatin adsorption and stability of the colloidal dispersion of gelatin-coated magnetic iron oxide nano-particles. Adsorpt. Sci. Technol. 2008, 26, 279-290. [CrossRef]

60. Suarasan, S.; Focsan, M.; Maniu, D.; Astilean, S. Gelatin-nanogold bioconjugates as effective plasmonic platforms for SERS detection and tagging. Colloids Surf. B 2013, 103, 475-481. [CrossRef]

61. Huang, J.; Wang, L.; Lin, R.; Wang, A.Y.; Yang, L.; Kuang, M.; Qian, W.; Mao, H. Casein-coated iron oxide nanoparticles for high MRI contrast enhancement and efficient cell targeting. ACS Appl. Mater. Interfaces 2013, 5, 4632-4639. [CrossRef] [PubMed]

62. Alqahtani, M.S.; Islam, M.S.; Podaralla, S.; Kaushik, R.S.; Reineke, J.; Woyengo, T.; Perumal, O. Food Protein Based Core-Shell Nanocarriers for Oral Drug Delivery: Effect of Shell Composition on in Vitro and in Vivo Functional Performance of Zein Nanocarriers. Mol. Pharm. 2017, 14, 757-769. [CrossRef] [PubMed]

63. Ashraf, S.; Abbasi, A.Z.; Pfeiffer, C.; Hussain, S.Z.; Khalid, Z.M.; Gil, P.R.; Parak, W.J.; Hussain, I. Protein-mediated synthesis, $\mathrm{pH}$-induced reversible aggregation, toxicity and cellular interaction of silver nanoparticles. Colloids Surf. B 2013, 102, 511-518. [CrossRef] [PubMed]

64. Fahmi, M.Z.; Ou, K.-L.; Chen, J.-K.; Ho, M.-H.; Tzing, S.-H.; Chang, J.-Y. Development of bovine serum albumin-modified hybrid nanoclusters for magnetofluorescence imaging and drug delivery. RSC Adv. 2014, 4, 32762-32772. [CrossRef]

65. Zhang, B.; Wang, X.; Liu, F.; Cheng, Y.; Shi, D. Effective reduction of nonspecific binding by surface engineering of quantum dots with bovine serum albumin for cell-targeted imaging. Langmuir 2012, 28, 16605-16613. [CrossRef] [PubMed]

66. Wang, X.; Xing, X.; Zhang, B.; Liu, F.; Cheng, Y.; Shi, D. Surface engineered antifouling optomagnetic SPIONs for bimodal targeted imaging of pancreatic cancer cells. Int. J. Nanomed. 2014, 9, 1601-1615. [CrossRef]

67. Strozyk, M.S.; Chanana, M.; Pastoriza-Santos, I.; Pérez-Juste, J.; Liz-Marzán, L.M. Protein/polymer-based dual-responsive gold nanoparticles with $\mathrm{pH}$-dependent thermal sensitivity. Adv. Funct. Mater. 2012, 22, 1436-1444. [CrossRef]

68. Molina-Bolívar, J.A.; Ortega-Vinuesa, J.L. How Proteins Stabilize Colloidal Particles by Means of Hydration Forces. Langmuir 1999, 15, 2644-2653. [CrossRef]

69. Moore, T.L.; Rodriguez-Lorenzo, L.; Hirsch, V.; Balog, S.; Urban, D.; Jud, C.; Rothen-Rutishauser, B.; Lattuada, M.; Petri-Fink, A. Nanoparticle colloidal stability in cell culture media and impact on cellular interactions. Chem. Soc. Rev. 2015, 44, 6287-6305. [CrossRef]

70. Laurentius, L.B.; Owens, N.A.; Park, J.; Crawford, A.C.; Porter, M.D. Advantages and limitations of nanoparticle labeling for early diagnosis of infection. Expert Rev. Mol. Diagn. 2016, 16, 883-895. [CrossRef]

71. Crowther, J.R. The ELISA Guidebook; Humana Press: New York, NY, USA, 2009; pp. 43-111.

72. Jain, S.; Mittal, A.; Jain, A.K.; Mahajan, R.R.; Singh, D. Cyclosporin a loaded PLGA nanoparticle: Preparation, optimization, In-Vitro characterization and stability studies. Curr. Nanosci. 2010, 6, 422-431. [CrossRef]

73. Bai, Y.; Song, M.; Cui, Y.; Shi, C.; Wang, D.; Paoli, G.C.; Shi, X. A rapid method for the detection of foodborne pathogens by extraction of a trace amount of DNA from raw milk based on amino-modified silica-coated magnetic nanoparticles and polymerase chain reaction. Anal. Chim. Acta 2013, 787, 93-101. [CrossRef] [PubMed]

74. Wiogo, H.T.R.; Lim, M.; Bulmus, V.; Gutiérrez, L.; Woodward, R.C.; Amal, R. Insight into serum protein interactions with functionalized magnetic nanoparticles in biological media. Langmuir 2012, 28, 4346-4356. [CrossRef] [PubMed]

75. Matta, L.L.; Alocilja, E.C. Emerging nano-biosensing with suspended MNP microbial extraction and EANP labeling. Biosens. Bioelectron. 2018, 117, 781-793. [CrossRef] [PubMed]

76. Peng, Q.; Zhang, S.; Yang, Q.; Zhang, T.; Wei, X.-Q.; Jiang, L.; Zhang, C.-L.; Chen, Q.-M.; Zhang, Z.-R.; Lin, Y.-F. Preformed albumin corona, a protective coating for nanoparticles based drug delivery system. Biomaterials 2013, 34, 8521-8530. [CrossRef] [PubMed]

77. Li, F.; Yang, G.; Aguilar, Z.P.; Xiong, Y.; Xu, H. Affordable and simple method for separating and detecting ovarian cancer circulating tumor cells using BSA coated magnetic nanoprobes modified with folic acid. Sens. Actuators B Chem. 2018, 262, 611-618. [CrossRef] 
78. Nairi, V.; Medda, S.; Piludu, M.; Casula, M.F.; Vallet-Regì, M.; Monduzzi, M.; Salis, A. Interactions between bovine serum albumin and mesoporous silica nanoparticles functionalized with biopolymers. Chem. Eng. J. 2018, 340, 42-50. [CrossRef]

79. Mirshafiee, V.; Kim, R.; Park, S.; Mahmoudi, M.; Kraft, M.L. Impact of protein pre-coating on the protein corona composition and nanoparticle cellular uptake. Biomaterials 2016, 75, 295-304. [CrossRef]

80. García-Álvarez, R.; Hadjidemetriou, M.; Sánchez-Iglesias, A.; Liz-Marzán, L.M.; Kostarelos, K. In vivo formation of protein corona on gold nanoparticles. The effect of their size and shape. Nanoscale 2018, 10, 1256-1264. [CrossRef]

81. Hu, Z.; Zhang, H.; Zhang, Y.; Wu, R.; Zou, H. Nanoparticle size matters in the formation of plasma protein coronas on $\mathrm{Fe}_{3} \mathrm{O}_{4}$ nanoparticles. Colloids Surf. B 2014, 121, 354-361. [CrossRef]

82. Simpson, R.J. Stabilization of proteins for storage. Cold Spring Harb. Protoc. 2010, 5. [CrossRef] [PubMed]

83. Borgstrom, B.; Dahlqvist, A.; Lundh, G.; Sjovall, J. Studies of intestinal digestion and absorption in the human. J. Clin. Investig. 1957, 36, 1521-1536. [CrossRef] [PubMed]

84. Langer, K.; Anhorn, M.G.; Steinhauser, I.; Dreis, S.; Celebi, D.; Schrickel, N.; Faust, S.; Vogel, V. Human serum albumin (HSA) nanoparticles: Reproducibility of preparation process and kinetics of enzymatic degradation. Int. J. Pharm. 2008, 347, 109-117. [CrossRef] [PubMed]

85. Elzoghby, A.O.; Helmy, M.W.; Samy, W.M.; Elgindy, N.A. Novel ionically crosslinked casein nanoparticles for flutamide delivery: Formulation, characterization, and in vivo pharmacokinetics. Int. J. Nanomed. 2013, 8, 1721-1732. [CrossRef] [PubMed]

86. Ninan, G.; Joseph, J.; Abubacker, Z. Physical, Mechanical, and Barrier Properties of Carp and Mammalian Skin Gelatin Films. J. Food Sci. 2010, 75, E620-E626. [CrossRef] [PubMed]

87. Kamal, A.M.; Salama, O.A.; El-Saied, K.M. Changes in amino acids profile of camel milk protein during the early lactation. Int. J. Dairy Sci. 2007, 2, 226-234. [CrossRef]

88. Stein, W.H.; Moore, S. Amino acid composition of beta-lactoglobulin and bovine serum albumin. J. Biol. Chem. 1949, 178, 79-91. [PubMed]

89. Silva, C.J.S.M.; Sousa, F.; Gübitz, G.; Cavaco-Paulo, A. Chemical Modifications on Proteins Using Glutaraldehyde. Food Technol. Biotechnol. 2004, 42, 51-56.

90. Cao, X.; Han, Y.; Li, F.; Li, Z.; McClements, D.J.; He, L.; Decker, E.A.; Xing, B.; Xiao, H. Impact of proteinnanoparticle interactions on gastrointestinal fate of ingested nanoparticles: Not just simple protein corona effects. NanoImpact 2019, 13, 37-43. [CrossRef]

91. Chanana, M.; Rivera-gil, P.; Correa-Duarte, M.A.; Liz-Marzán, L.M.; Parak, W.J. Physicochemical properties of protein-coated gold nanoparticles in biological fluids and cells before and after proteolytic digestion. Angew. Chem. Int. Ed. 2013, 52, 4179-4183. [CrossRef] 